\title{
Money shouts! How effective are punishments for accounting fraud?
}

Wang, Yang; Ashton, John K.; Jaafar, Aziz

\section{British Accounting Review}

\author{
DOI: \\ 10.1016/j.bar.2019.02.006
}

Published: 30/09/2019

Peer reviewed version

Cyswllt i'r cyhoeddiad / Link to publication

Dyfyniad o'r fersiwn a gyhoeddwyd / Citation for published version (APA):

Wang, Y., Ashton, J. K., \& Jaafar, A. (2019). Money shouts! How effective are punishments for accounting fraud? British Accounting Review, 51(5), [100824].

https://doi.org/10.1016/j.bar.2019.02.006

\footnotetext{
Hawliau Cyffredinol / General rights

Copyright and moral rights for the publications made accessible in the public portal are retained by the authors and/or other copyright owners and it is a condition of accessing publications that users recognise and abide by the legal requirements associated with these rights.

- Users may download and print one copy of any publication from the public portal for the purpose of private study or research.

- You may not further distribute the material or use it for any profit-making activity or commercial gain

- You may freely distribute the URL identifying the publication in the public portal ?
}

Take down policy

If you believe that this document breaches copyright please contact us providing details, and we will remove access to the work immediately and investigate your claim. 


\title{
Money shouts!
}

\section{How effective are punishments for accounting fraud?}

\author{
Yang Wanga, John K. Ashton ${ }^{b}$, Aziz Jaafar ${ }^{b}$
}

\begin{abstract}
This study examines the impact of different punishments for Chinese accounting fraud on shareholder valuation of firms between 2007 and 2016. From an examination of both monetary and non-monetary 'name and shame' penalties, it is reported all punishments have a negative and significant impact on the shareholder wealth of fraudulent firms. Investors perceive punishments involving monetary penalties far more severely than non-monetary punishments used to combat accounting fraud. Stock market reactions are also sensitive to the type of fraud committed with manipulation of recognition and disclosure fraud viewed more negatively by investors than fraud related to disclosure. Information leakage to capital markets prior to the announcement of punishments is also observed. It is proposed fines have been relatively more effective, than 'name and shame' punishments in addressing Chinese accounting fraud during the last decade, due not least to information leakage.
\end{abstract}

Key words: Accounting fraud, Event study, Information leakage, Punishment, Stock market reaction

JEL Classification: G3 K2 K4 M40

* Corresponding author

${ }^{a}$ Division of Business and Management, United International College, Beijing Normal University-Hong Kong Baptist University, Guangdong, China.

b Bangor Business School, Bangor University, Bangor, Wales, UK

Email address: yangwang@uic.edu.hk (Y.Wang), j.ashton@bangor.ac.uk (J.K. Ashton), a.jaafar@bangor.ac.uk (A. Jaafar) 


\section{Money shouts! How effective are punishments for accounting fraud?}

\section{Introduction}

Effective punishments are a crucial element of any fraud prevention program and signal the regulator's anti-fraud stance. Punishments imposed on fraudulent firms must produce sufficient costs to outweigh the expected gains from fraud (Werden, 2009; Steinway, 2014). Further, if the punishments and enforcement mechanisms are effective the subsequent stock market reaction should increase the costs of fraud (Quan \& $\mathrm{Li}$, 2017). Using a unique hand collected data set of financial statement fraud by Chinese listed firms between 2007 and 2016, this study examines the link between a range of monetary and non-monetary 'name and shame' punishments and associated stock market reactions. ${ }^{1}$

Due to the rapid development of its economy and capital markets, the research context explored is China. China has the world's second largest economy and capital markets with economic output of $\$ 12.01$ trillion and a market capitalization of $\$ 8.71$ trillion in 2017 (World Bank, 2018). Major regulators of corporate conduct in China are the China Securities Regulatory Commission (CSRC), CSRC regional offices, stock exchanges and Ministry of Finance. These regulators can impose different punishments on fraudulent firms including fines, warnings, rectification notices, letters of warning, statements of regulatory concern, public criticism and public condemnation. The CSRC is the major securities regulator and its functions are similar to those of the U.S. Securities and Exchange Commission (SEC). However, Chinese investor protection and law enforcement level is relatively weak and public laws in China are often under or selectively enforced (Chen, Cumming, Hou, \& Lee, 2016). Subsequently, a weak legal environment provides opportunities for the manipulation of financial statements.

1 To provide a more accurate estimation of investor reaction, samples are restricted into financial statement fraud. Most previous research on the economic consequences of fraud in China brings all types of fraud into scope e.g. financial fraud, market manipulation, insider trading and even corporate environment pollution (Aggarwal, Hu, \& Yang, 2015). Given the differences in the nature of fraud, findings cannot be automatically generalized from the one to another. 
In addition, most Chinese listed firms have a highly concentrated ownership structure, with often a single owner having effective control of the listed firm. As many of these controlling shareholders are state and quasi-state institutions, China's corporate ownership structure offers a unique research setting (Jiang \& Kim, 2015) very different to that seen in the U.S. or UK.

This investigation is important as an effective punishment regime is essential for firms, regulators and investors. For firms, the public exposure of punishment underlines the unacceptability of the fraudulent behaviours and evokes public disapproval of wrongdoing. Negative publicity can foster normative attitudes against firm fraud and increase their willingness to invest in 'beyond-compliance' behaviours (Parker, 2006). For regulators, when the public becomes aware punishments are imposed for fraudulent behaviours, confidence in market supervision increases. An effective punishment mechanism therefore augments the legitimacy of supervision, creating a 'tough' image of public enforcement. For investors, an effective punishment mechanism alleviates information asymmetries in capital markets and incorporates conduct risks within investment decisions (Van-Erp, 2014).

The empirical results show that stock market reactions to all punishments have been significant and negative. In particular, punishments involving monetary fines have a far stronger negative influence on stock market returns than other penalties. Stock market investors also discriminate among different types of fraud with investors reacting less negatively to the disclosure of fraud than the combination of recognition and disclosure of fraud. This study further shows that information leakage occurs before the announcement of formal sanction decisions. We report informed investors using this leaked information, view fines more negatively than other punishments. It is proposed within an environment of information leakage the potency of 'name and shame' penalties is reduced relative to monetary punishments.

By examining monetary and non-monetary punishments in a Chinese context, this paper provides incremental contributions to the extant literature examining the regulation of fraud. First, the impact of both monetary penalties such as fines and non- 
monetary, 'name and shame' penalties are examined. The latter are often omitted in assessments of accounting fraud, despite longstanding concerns that imposing fines can become unfair and inefficient (Goodhart, 2017) or even amplify the behaviours of concern (Gneezy and Rustichini, 2000). Different from prior studies examining the effectiveness of fines, a statistical analysis is applied which overcomes practical difficulties involved in conducting field experiments (Holmas et al., 2010). In addition, previous studies on information leakage commonly focus on analyst recommendations (Lin and Lu, 2015), mergers and acquisitions (Anagnostopoulou and Tsekrekos, 2015) and share repurchase (Hao, 2016). The study complements this stream of literature by addressing the impact of information leakage on regulatory punishments and providing new evidence that informed investors rationally give monetary penalties greater weights than others punishments. This enables policy setters to assess the effectiveness of punishments and set stringent regulations to curb information leakage and insider trading. The implications drawn from this study are useful in understanding the effectiveness of punishments and related stock market reaction within developing economies with a similar legal environment.

Second, the literature on Chinese accounting fraud (Chen et al., 2005; Sun and Zhang, 2006) is extended by considering cases punished by the regional offices of the CSRC. These previously overlooked regional offices of the securities regulator account for more than $75 \%$ of the CSRC's staffing (Xu and $\mathrm{Xu}, 2017$ ) and use non-monetary punishments more frequently than CSRC central offices. By incorporating sanction decisions of regional offices in this assessment, the study finds the CARs triggered by punishment announcements are lower than other Chinese studies (Firth et al., 2009; Wu and Zhang, 2014). This implies punishments imposed by regional offices do not generate economically significant impacts on listed firms. In addition, this paper considers different supervisory measures imposed by regional offices, which has been overlooked by prior studies. Empirical findings suggest these supervisory measures are not perceived as severe retributive punishments by investors. Subsequently, it underscores the importance for future studies to include these cases as they have a 
significant impact on the empirical results.

The remainder of the study is organized as follows: The next section reviews the institutional background, theoretical framework, prior empirical findings and develops hypotheses. The third section discusses the data and the empirical approach. The fourth section reports the empirical results and the final section concludes the paper.

\section{Literature review}

\subsection{Institutional background: regulatory enforcement}

China adopts a centralized approach to regulatory enforcement, in which the CSRC plays a key role by inspecting fraudulent activities committed by listed firms and imposing administrative punishments or non-administrative punishments to deter corporate fraud. Table 1 provides a brief comparison of the different types of punishments. Warnings are administrative sanctions used to caution listed firms and enable relevant individuals (investors) to be 'mentally alert' (Zhang \& Zhao, 2007). The rectification notices, regulatory concern and letters of warning are highly timesensitive supervisory measures ${ }^{2}$ (CSRC, 2014). Regarding general problems, CSRC regional offices can issue letters of regulatory concern. In the case of moderately serious problems, the regulators can issue letters of warning or rectification notices to listed firms (CSRC, 2012). Public criticism and public condemnation are self-disciplinary measures $^{3}$ that apply only to non-serious fraud with relatively minimal effects $(\mathrm{Xu}$, Chen, $\&$ Xu, 2017). Monetary fines are regarded as a severe administrative punishment, with amounts ranging from 300,000 Yuan to 600,000 Yuan $(\$ 45,000$ to $\$ 90,000)$ levied from firms against misrepresentation. Any punishment would result in increased

\footnotetext{
2 The details can be found in the Rules of Listed Firms' on-site Inspections. Available at: http://www.csrc.gov.cn/pub/csrc en/newsfacts/release/200902/t20090203_69256.html (last visited on 17 May, 2018).

3 See the Implementation Details of Self-regulatory Measures and Disciplinary Actions promulgated by the Shenzhen Stock Exchange and the Shanghai Stock Exchange. Available at: https://www.szse.cn/main/en/RulesandRegulations/SZSERules/GeneralRules/, http://english.sse.com.cn/laws/framework/c/3978489.pdf (last visited on 17 May, 2018). 
regulatory scrutiny for the firm's future refinancing, merger and acquisition activities and can be considered within future judgments (CSRC, 2013).

\section{Table 1}

Types of punishments.

\begin{tabular}{|c|c|c|c|c|c|c|}
\hline Punishments & $\begin{array}{l}\text { Commonly } \\
\text { used by } \\
\text { which } \\
\text { regulator }\end{array}$ & $\begin{array}{l}\text { Regulation } \\
\text { basis }\end{array}$ & $\begin{array}{l}\text { Nature of } \\
\text { punishments }\end{array}$ & $\begin{array}{l}\text { Severity } \\
\text { level } \\
\text { across } \\
\text { groups }\end{array}$ & $\begin{array}{l}\text { Severity } \\
\text { level } \\
\text { within } \\
\text { group }\end{array}$ & $\begin{array}{l}\text { Monetary or } \\
\text { non-monetary } \\
\text { punishment }\end{array}$ \\
\hline Fines & \multirow{2}{*}{$\begin{array}{l}\text { CSRC } \\
\text { central } \\
\text { offices, } \\
\text { Ministry } \\
\text { of Finance }\end{array}$} & \multirow[b]{2}{*}{ Laws } & \multirow{2}{*}{$\begin{array}{l}\text { Administrative } \\
\text { sanctions }\end{array}$} & \multirow[b]{2}{*}{ Severe } & Severe & $\begin{array}{l}\text { Monetary } \\
\text { punishment }\end{array}$ \\
\hline Warning & & & & & $\begin{array}{l}\text { Less } \\
\text { severe }\end{array}$ & \multirow{6}{*}{$\begin{array}{l}\text { Non-monetary } \\
\text { punishments }\end{array}$} \\
\hline $\begin{array}{l}\text { Rectification } \\
\text { notice }\end{array}$ & \multirow{3}{*}{$\begin{array}{l}\text { CSRC } \\
\text { regional } \\
\text { offices }\end{array}$} & \multirow{3}{*}{$\begin{array}{l}\text { Departmental } \\
\text { provisions }\end{array}$} & \multirow{3}{*}{$\begin{array}{l}\text { Supervisory } \\
\text { measures } \\
\text { (Non- } \\
\text { administrative } \\
\text { sanctions) }\end{array}$} & & & \\
\hline $\begin{array}{l}\text { Letter of } \\
\text { warning }\end{array}$ & & & & Moderate & Severe & \\
\hline $\begin{array}{l}\text { Regulatory } \\
\text { concern }\end{array}$ & & & & & $\begin{array}{l}\text { Less } \\
\text { severe }\end{array}$ & \\
\hline $\begin{array}{l}\text { Public } \\
\text { condemnation }\end{array}$ & \multirow[b]{2}{*}{$\begin{array}{l}\text { Stock } \\
\text { exchanges }\end{array}$} & \multirow[b]{2}{*}{$\begin{array}{l}\text { Self- } \\
\text { regulations }\end{array}$} & $\begin{array}{l}\text { Self- } \\
\text { regulatory }\end{array}$ & \multirow[b]{2}{*}{ Minor } & Severe & \\
\hline $\begin{array}{l}\text { Public } \\
\text { criticism }\end{array}$ & & & $\begin{array}{l}\text { measures } \\
\text { (Non- } \\
\text { administrative } \\
\text { sanctions) }\end{array}$ & & $\begin{array}{l}\text { Less } \\
\text { severe }\end{array}$ & \\
\hline
\end{tabular}

In order to better understand these enforcement mechanisms, the types of enforcement actions taken by the U.S., UK and China's securities regulators are compared in the Table 2. In the U.S., the SEC takes either administrative or civil actions against fraudsters. Similarly, the UK's Financial Conduct Authority (FCA) is also allowed to issue civil proceedings in the high court to address accounting fraud. Civil actions are not allowed to be taken by the Chinese securities regulators. The SEC has increasingly relied on the monetary penalties with an average annual growth rate of $30 \%$ since 2000 (Steinway, 2014). In contrast, the FCA and the CSRC rely more on non-monetary penalties to punish perpetrators. For instance, the average use of financial penalties to the total enforcement actions taken by the FCA was 31\% from 2011 to 2014 (FCA, 
2015).

\section{Table 2}

A comparison of enforcement actions across countries.

\begin{tabular}{|c|c|c|c|}
\hline Country & U.S. & UK & China \\
\hline $\begin{array}{l}\text { Securities } \\
\text { regulator }\end{array}$ & SEC & $\mathrm{FCA}(\mathrm{FSA})^{4}$ & CSRC \\
\hline $\begin{array}{l}\text { Civil actions can } \\
\text { be taken by the } \\
\text { securities regulator }\end{array}$ & Yes & Yes & No \\
\hline $\begin{array}{l}\text { Proportion of civil } \\
\text { actions by } \\
\text { securities regulator } \\
\text { to total } \\
\text { enforcement } \\
\text { actions }\end{array}$ & High & Low & None \\
\hline $\begin{array}{l}\text { Major types of } \\
\text { sanctions }\end{array}$ & $\begin{array}{l}\text { Cease and desist } \\
\text { orders, suspension or } \\
\text { revocation of broker- } \\
\text { dealer and investment } \\
\text { advisor registrations, } \\
\text { censures, bars from } \\
\text { association with the } \\
\text { securities industry, } \\
\text { monetary penalties and } \\
\text { disgorgements }\end{array}$ & $\begin{array}{l}\text { Variation/ cancellation/ } \\
\text { refusal of authorisation/ } \\
\text { approval/permissions, } \\
\text { financial penalties, } \\
\text { public censure, } \\
\text { prohibition and } \\
\text { suspension }\end{array}$ & $\begin{array}{l}\text { Warning, fines, } \\
\text { disgorgement of illegal } \\
\text { gains, banning of market } \\
\text { entry, rectification } \\
\text { notice, regulatory } \\
\text { concern and letter of } \\
\text { warning, public } \\
\text { statements and } \\
\text { regulatory interview }\end{array}$ \\
\hline $\begin{array}{l}\text { Greater reliance on } \\
\text { monetary or non- } \\
\text { monetary } \\
\text { penalties? }\end{array}$ & Monetary penalties & Non-monetary penalties & Non-monetary penalties \\
\hline
\end{tabular}

Figure 1 shows the typical sequence of events within an enforcement action. Regulatory investigations are commonly triggered by whistleblowers, firms' self-disclosure of malfeasance, restatements, auditor departures, unusual trading and regulators' routine supervision (Karpoff, Lee, \& Martin, 2008). If an official investigation is undertaken, the case will be referred to the enforcement department and investigated. When a case is deemed to be an administrative offence, the investigation notification is disclosed to

4 Since the 1st April 2013, the Financial Services Authority has been replaced by the Prudential Regulatory Authority and the Financial Conduct Authority. 
the public. In contrast, the initial investigation notification is not publically disclosed if a case is not considered to be an administrative offence (CSRC, 2016).

Before deciding to impose any administrative penalties, regulators have responsibilities to report the facts, grounds and regulatory basis of judgments (National People's Congress, 2009). Once punishment files are approved by regulators, these are first sent to the listed firms and then made to public through designated national financial newspapers or the regulators' official websites.

Fraud period

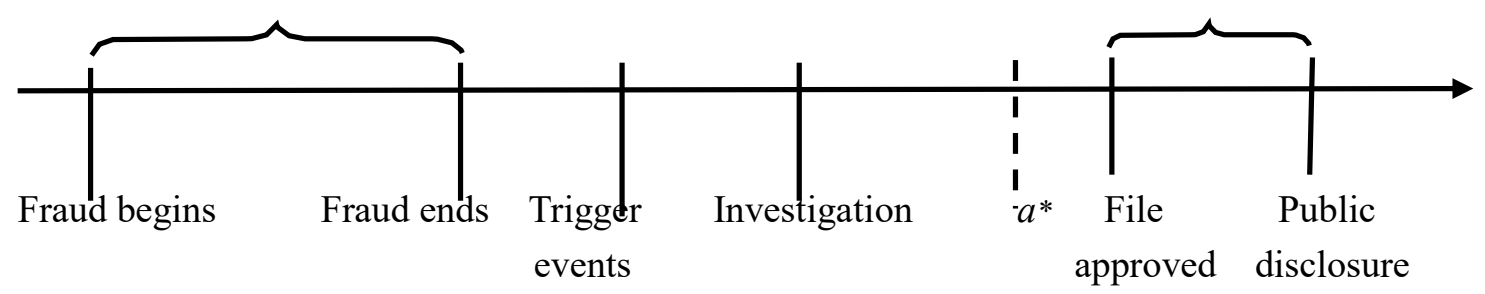

Fig. 1 Timeline of an enforcement action.

Notes: $a^{*}$ represents the announcement of advance notice of a sanction decision, which is only applicable when the sanction decision is administrative in nature.

\subsection{Theoretical framework and prior empirical findings}

The choice to commit accounting fraud and subsequent punishments can also be viewed as an economic decision involving a cost and benefit trade-off. A manager's likelihood of committing fraud depends on his or her perception of the probability of detection, the severity of expected punishments and the gains from fraud (Becker, 1968). A manager would therefore commit fraud, when punishments and the probability of capture are lower than the benefits obtained (Baucus \& Baucus, 1997). To deter fraud, punishments must therefore produce sufficient disutility to outweigh gains from fraudulent behaviours (Werden, 2009). Such a relationship is not straightforward and may be affected by psychological factors. For instance, using an 'inspection game', Nosenzo, Offerman, Sefton and van der Veen (2013) report fines were more effective 
in deterring non-compliance, than bonuses were in encouraging compliance. In summary, the effectiveness of legal punishments in deterring offending depends on the certainty, severity and celerity of punishments.

While these direct rewards from fraud can be attractive to perpetrators, offending creates a diversity of costs. First, firms that engage in fraudulent behaviours incur direct costs including regulatory fines and court-imposed penalties (Zeidan, 2013). Second, fraudulent firms can face a wide range of reputational costs often exceeding legal penalties (Karpoff \& Lott, 1993). The intangible reputational costs reflect the capitalization of expected losses resulting from deteriorated relationships with firm owners (shareholders), customers, financiers, managers and suppliers (Autore, Hutton, Peterson, \& Smith, 2014). For instance, trading partners may become skeptical about the firm's future financial statements and adversely revise terms of trade increasing contracting costs. Similarly, finance providers may offer less generous terms to fraudulent firms (Armour, Mayer, \& Polo, 2017) and customers may punish fraudulent firms through lower sales or boycott. For managers, punishments may redirect actions towards remedying the consequences of punishments rather than profitable projects (Aguzzoni, Langus, \& Motta, 2013). For shareholders, a diversity of responses may arise. A damaged reputation can deter investment in the fraudulent firms and increase the cost of capital (Zeidan, 2013). Shareholders may also undertake legal actions against fraudulent firms. Equally, shareholders may sell shares in fraudulent firms, reducing the offenders' market valuation. This last issue has been the focus of a considerable international literature, assessing the reputational costs imposed by corporate punishments.

There are also geographical differences in stakeholders' perceptions of regulatory punishments specific to China. The existence of Guanxi, a Chinese term for personal relationships (Chen, Cheng, Gong, \& Tan, 2014) may lessen the effects of fraudulent firms' relationship with stakeholders. With greater financial and regulatory resources from the state, stakeholders may perceive Guanxi-connected firms are more likely to recover from punishments and reevaluate their investment decisions accordingly (Chen 
et al., 2016).

The reputational effects punishments impose been examined internationally within examinations of shareholder wealth losses such as CARs using event study approaches. Most work has considered market responses to regulatory announcements, with a smaller literature considering how markets respond to the imposition of different types of penalties.

Studies examining market responses to regulatory announcements have consistently reported negative responses to the disclosure of regulatory announcements (see Karpoff et al., 2008). For example, in the U.S., abnormal returns of $-5.3 \%$ on the announcement day of financial restatements have been reported (Palmrose, Richardson, \& Scholz, 2004). Similarly for the UK, Armour et al. (2017) report regulatory enforcement actions led to CARs of $-1.26 \%$ on the event day and a CAR of $-1.68 \%$ over a 3 -day event window for offending firms. An increasing number of Chinese studies have also examined if stock market reactions to the announcement of fraud was accompanied by a decline of $-1 \%$ to $-2 \%$ in affected firms' stock prices in a short-term event window (Wu \& Zhang, 2014). For instance, Chen et al. (2005) identify 169 firms disciplined by the CSRC and two stock exchanges, reporting enforcement actions had a negative impact on the stock returns of $-1.8 \%$ in a five-day event window. Similarly, Sun and Zhang (2006) examine the announcement of enforcement sanctions reporting the average CAR was $-1.4 \%$.

Market reactions to individual fraud punishments have also been examined. For China, Quan and Li (2017) report fines had a negative influence on firm values. Examinations of the costs imposed by non-monetary penalties on firm value have been more piecemeal. For instance within China the effects of punishments imposed on independent directors was deemed to be significantly negative (Quan \& Li, 2017) and that markets react more negatively to constraints placed on a director's current and future employment and promotion opportunities than monetary penalties (Hung, Wong, \& Zhang, 2015). 
When considering the costs imposed by different forms of punishments, fines have often been the primary focus of interest due to their gravity and multiple effects. For instance, fines can impose large reputational costs (Sun \& Zhang, 2006, Karpoff, Lee, \& Martin, 2007), directly reduce corporate cash flows and existing assets and alter investors' expectations of firm liquidity and future earnings. These monetary punishments are sometimes supplemented with non-monetary, 'name and shame' punishments. These punishments aim to directly degrade firm reputations through public denunciation (Zhang \& Zhao, 2007), imposing a wider social costs on firms (D'Antoni \& Galbiati, 2005) and deterring listed firms from committing fraud (Karpoff et al. 2007).

Empirical findings are mixed with regards to the efficiency of fines. Cherry (2001) provides evidence that financial penalties such as fines and forfeitures provide a considerable deterrent effect comparable to those provided by prison sentences. Cherry suggests policymakers should reconsider financial penalties as an alternative to criminal sanctions these can significantly reduce criminal justice expenditure. In contrast, Gneezy and Rustichini (2000) examine whether fines can reduce the occurrence of the late-arrival behaviour and report fines do not change the sanctioned behaviour. Similarly, Holmas et al. (2010) analyze the impact of fining owners of longterm care institutions who prolong length of stay at hospitals. They find hospital length of stay is longer when monetary fines are introduced.

Market reactions to regulatory announcements also vary with the type of fraudulent behaviours addressed such as income statement fraud and disclosure fraud (Zhu \& Gao, 2011). Income statement fraud is thought to elicit the strongest negative response from investors, as such restatements affect central business operations (Kravet \& Shevlin 2010). Anderson and Yohn (2002) find that negative market reaction is most pronounced for firms with revenue recognition restatements in U.S. Similarly, Desai, Hogan and Wilkins (2006) state financial restatements caused by improper revenue (cost) recognition generate a large CARs of $-14.89 \%$. In China income performance is an important criteria for firm authorization of IPO and right issues and avoidance of 
delisting. Income statement fraud is also positively associated with the likelihood of shareholder litigation, suggesting that investors regard the income statement manipulation as serious fraud and signaling the capital market that management is incompetent (Palmrose \& Scholz, 2004).

Investors could also treat omitted or improperly disclosed and recognized information distinctly (Michels, 2017). Recognized information is reported in the consolidated financial statements, while disclosed information is stated in the notes to the financial statements and other sections. ${ }^{5}$ Due to its positioning investors may perceive recognized information as more reliable than disclosed information with the latter easier to manipulate and more tolerated by auditors. In addition, recognized information (i.e. accounting earnings) is typically specified in executive compensation contracts. Therefore, managers are likely to engage in fraud to meet the requirements of recognized information and obtain more performance-linked-salary (Li, Lou, Wang, \& Yuan, 2013). Prior empirical findings also indicate that earnings restatements have had a far greater negative influence than restatement of omitted and restated notes or disclosure (Robbani \& Bhuyan, 2010).

\subsection{Hypotheses development}

This study assumes fraud occurs as perpetrators believe the benefits obtained from fraud outweigh the costs of punishment and probability of being caught. As a fine is one of the most severe administrative punishments which can be imposed on a listed firm (Firth et al., 2016), monetary penalties should lead to more severe effects on shareholder wealth than non-monetary penalties. In addition, according to the CSRC regulatory documents, severe punishments are imposed on firms if their acts are particularly adverse, disturbing the order of the securities market and incurring serious

5 These sections include corporate governance, internal control, share changes and shareholders, important matters, reports of the board of directors and summary of accounting data and financial indicators sections. These sections are the contents and formats standards required by the CSRC with regards to compile annual reports (CSRC, 2014). 
social impacts or damage to the interests of investors (CSRC, 2008). Compared to nonmonetary punishments, imposing fines signal the seriousness of fraud, thus generating considerable negative effects on a firm's stock prices.

Empirical support for the effectiveness of monetary penalty has been reported by some prior studies. For instance, Kurz et al. (2014) report that when a fine for late-coming is framed in a retributive way rather than a compensatory way, people experienced latecoming to a larger extent as moral transgression. Swanepoel and Meiring (2018) find that fines are more effective than imprisonment for fraud, corruption or tax-related offences. In addition, if the level of fines cannot be raised further, it would be appropriate to supplement such fines with a prison term for fraud. Subsequently, the use of fines can better achieve the deterrent and retributive goals of punishment (Chen et al., 2011). Therefore, this study posits the following hypothesis.

$H_{1}$ : $\quad$ Fines result in a more negative stock market reaction than non-monetary punishments.

As different types of fraud illicit distinct market reactions, the type of fraud perpetuated is examined. The manipulation of recognition items affects corporate core accounts. These accounts reflect the central operations of the business, which are essential for financial reporting users to forecast future earnings and cash flows (Kravet and Shevlin, 2010). Subsequently, stock returns decrease more for restatements affecting corporate core earnings ( $\mathrm{Du}, 2017)$. Consistent with this argument, Li et al. (2018) find that financial restatements caused by improper revenue recognition generate a significant CARs of $-1.9 \%$ over a three-day event window.

Concerns can also arise when managers strategically obfuscate using legal jargon and technical accounting terms (Amel-Zadeh and Faasse, 2016). Such practices can create information overload for investors (Hirshleifer and Teoh, 2003); a practice seen to be particularly acute for disclosure items (Hirst et al., 2004). Subsequently, investors tend to underestimate the importance of disclosed information. Israeli (2015) finds evidence that investors place smaller valuation weights on disclosed than on recognized 
analogous Statement of Financial Position and Income Statement amounts. This suggests that market participants do not perceive disclosed information as a substitute for recognized information in determining a firm's value. Such a valuation effect is stronger if firms manipulate both recognition and disclosure items, signaling the severity of fraudulent behaviours and the ineffectiveness of internal control mechanisms. As a result, investors may react more to punishments for both recognition and disclosure fraud than single disclosure fraud. Hence, this study proposes the following.

H2: $\quad$ Markets react more negatively to both recognition and disclosure fraud than only to disclosure fraud.

Previous studies of Chinese capital markets report significant abnormal returns prior to mergers and acquisitions (Anagnostopoulou and Tsekrekos, 2015) and share repurchase announcements (Hao, 2016). The announcements are leaked to the capital market before formal disclosure and involve illegal insider trading activities. Unlike other developed stock markets, trading on Chinese capital markets is mostly undertaken by individuals rather than institutional investors (Reuters, 2015). This exacerbates freerider problems, increases information asymmetries and enhances the possibility of information leakage. Therefore, information leakage occurring prior to the punishment announcements is expected.

Information leakage may also be used strategically by managers to soften the impact of regulatory announcements. That is, managers have incentives to leak punishment news to selected influential investors (i.e. controlling shareholders and board of directors) who may trade on this news prior to its public announcement (Campbell et al., 2016). Additionally, regulatory insiders could leak punishment information to their stakeholders and profitably trade on such information (Huang, 2007). Consistent empirical findings are reported by Song and Han (2017), who find stock returns drop significantly prior to the announcement of corporate wrongdoings in South Korea. Within an environment with information leakage, informed investors perceive fines as the most severe punishment, as fines are retributive rather than compensatory (Kurz et 
al., 2014). In other words, an informed investor is more likely to see fines as a means by which one is punished for breaching regulations rather than an opportunity to compensate the victims of fraudulent activities. Therefore, this study hypothesizes:

\section{$H_{3}: \quad$ There is information leakage prior to the announcement of punishment information and informed investors perceive fines more severely than other punishments.}

\section{Data and research design}

This study uses a hand-collected dataset of regulatory determinants (i.e. punishments, fraud and duration) based on the sanction reports issued by regulators. The stock returns, financial and corporate governance data are collected from the CSMAR database. The sample period runs from 2007 to 2016 to accommodate new accounting standards adopted in 2007. Cases where initial announcement dates are unavailable are excluded, leaving the final sample of 433 fraud cases. ${ }^{6}$

An event study methodology is used as it measures the impact of unanticipated events on stock prices. The event date is defined as the earliest date that the market learns a firm is subject to a sanction decision. This study chooses a 140-day estimation period comprising trading days $[-155,-16]$ and several different event windows, (i.e. $[0,2]$, $[-1,1],[-1,2],[-2,2],[-3,3],[-5,5])$ to capture the shareholder wealth effect of punishments (Chen et al., 2005). For a stock to be included in the sample, it must have no missing return data in the event window and at least two-thirds of daily stock return

\footnotetext{
${ }^{6}$ The initial search reports 794 available fraud cases. This study excludes 187 cases where the initial disclosure dates of punishments are unavailable. These 187 cases are only shown in the files named Announcement on Supervision Measures or Penalties or Rectifications Taken by Securities Regulatory Authorities and Stock Exchange against the Company in Past 5 Years, which are separate files issued by listed firms in order to summarize punishments imposed in last five years. For the remaining fraud cases, stock return data is downloaded with 461 cases having sufficient daily trading data for further analysis. For firms that are punished by regulators multiple times in the same reporting year, the final punishment case of each firm is included because the impacts of previous punishment announcements on stock prices have been incorporated in the estimation windows of the capital asset pricing model. Subsequently, 433 fraud cases are obtained for assessment.
} 
data available in the estimation window (Agrawal \& Cooper, 2015). The returns of the value-weighted market index (Shanghai \& Shenzhen) is used as benchmark returns. Moreover, the daily stock returns have been adjusted for cash dividends reinvested (Cheung, Jiang, Limpaphayom, \& Lu, 2010).

Normal returns are estimated based on the capital asset pricing model (see MacKinlay, 1997), which reflects a linear relationship between the excess return of an individual stock and the excess return of market portfolios.

$$
E\left(R_{i, t}\right)=R_{f, t}+\beta_{i}\left(R_{m, t}-R_{f, t}\right)
$$

Where $R_{i, t}$ is the actual rate of return of stock $i$ on day $\mathrm{t}, R_{m, t}$ is the rate of return of a market portfolio of stocks on day $\mathrm{t}, R_{f, t}$ is the daily risk-free interest rate and $\beta_{i}$ is the systematic risk of stock $i$. The difference between actual and normal stock returns represents the stock market reaction to the announcement of sanction decisions and is termed abnormal returns (Kouwenberg \& Phunnarungsi, 2013). Having obtained the abnormal returns for stock $i$, all the abnormal returns over the time period can be aggregated to the value of cumulative abnormal returns.

$$
A R_{i, t}=R_{i, t}-E\left(R_{i, t}\right)
$$

An appropriate empirical approach is determined following pre-testing of the data. Heteroskedasticity and autocorrelation are assessed using Modified Wald and Wooldridge tests. The dataset displays heteroskedasticity but no serial correlation. Therefore, a panel data regression is adapted to examine the effectiveness of punishments. A Hausman test indicates that a fixed effects model is appropriate, a Breusch-Pagan Lagrange multiplier test confirms that a random effect model is not appropriate and further tests verify time or industry fixed effects are not required. ${ }^{7}$ Subsequently, following Kim and Zhang (2016), a firm fixed effects regression model is used. Standard errors are adjusted for firm-level clustering as some firms have

\footnotetext{
${ }^{7}$ Joint $\mathrm{F}$ tests indicate that the coefficients for all years (and industries) are jointly equal to zero, therefore no time fixed effects or industry fixed effects are needed in this case. This test is undertaken using the Stata procedure TestParm (Ashton \& Hudson, 2014).
} 
repeatedly committed fraud over years (Ewelt-Knauer, Knauer, \& Lachmann, 2015). A dynamic panel data model is not used as the lagged dependent variable i.e. lagged CARs are the stock market reaction to a random event, thus do not have any economic meaning relating to fraud. The regression model is estimated as follows (Yu, 2013).

$$
\text { CARs }_{i t}=\beta_{0}+\beta_{i} \text { test } \text { variables }_{t}+\gamma_{i} \text { control variables } \text { va }_{t-1}+\alpha_{i}+\varepsilon_{i t}
$$

$\beta_{i}$ and $\gamma_{i}$ represent the coefficients to be estimated, $\alpha_{i}$ is the firm fixed effects and $\varepsilon_{i t}$ is the error term. When examining the relationships between stock market reaction and different punishments or fraud, following Firth et al. (2016) and Chen et al. (2016), the dependent variable CARs is based on a $[-2,2]$ event window. To examine information leakage, CARs over a pre-event window $[-15,-6]$ are used as the dependent variable. Test variables include both punishment and fraud dummy variables. There are seven punishment variables including warnings, fines, criticism, condemnation, rectification notices, regulatory concern and letters of warning. The fraud variables capture the type of fraud including recognition fraud, disclosure fraud and both recognition and disclosure fraud. ${ }^{8}$ Warnings and recognition fraud are selected as the reference groups in this study.

Fraud duration reflects the effectiveness of internal control and external supervision and is used as a control variable. As greater fraud duration signals the ineffectiveness of corporate internal control mechanisms and the likelihood of further bad news, this variable is expected to be negatively associated with investor reaction (Zhu \& Gao, 2011). Firm size is also considered, as larger firms are better equipped to bear the expenses of monetary penalties and defending lawsuits after fraud announcements.

\footnotetext{
${ }^{8}$ Following Zhu and Gao (2011), a content analysis method is used to code different types of fraud. Recognition fraud includes manipulation of income statements, balance sheets, cash flow statements and improper financial statements consolidation. Disclosure fraud includes delayed disclosure of annual reports and insufficient or false disclosure of information.
} 


\section{Table 3}

Variable definition and sources.

\begin{tabular}{|c|c|c|c|}
\hline Variable & Variable name & Description & Source \\
\hline $\begin{array}{l}\text { Dependent } \\
\text { variable }\end{array}$ & CARs & $\begin{array}{l}\text { Cumulative abnormal returns is measured over a }(-2,2) \text { event } \\
\text { window }\end{array}$ & CSMAR \\
\hline \multirow{7}{*}{$\begin{array}{l}\text { Test } \\
\text { variables - } \\
\text { Punishments }\end{array}$} & $\begin{array}{l}\text { Warnings } \\
\text { (Reference group) }\end{array}$ & $\begin{array}{l}\text { Equals to one if a firm is subject to a warning and zero } \\
\text { otherwise }\end{array}$ & Manual \\
\hline & Criticism & $\begin{array}{l}\text { Equals to one if a firm is subject to public criticism and zero } \\
\text { otherwise }\end{array}$ & Manual \\
\hline & Condemnation & $\begin{array}{l}\text { Equals to one if a firm is subject to public condemnation and } \\
\text { zero otherwise }\end{array}$ & Manual \\
\hline & Fines & Equals to one if a firm is subject to fines and zero otherwise & Manual \\
\hline & $\begin{array}{l}\text { Rectification } \\
\text { notice }\end{array}$ & $\begin{array}{l}\text { Equals to one if a firm has received a rectification notice from } \\
\text { a regulator and zero otherwise }\end{array}$ & Manual \\
\hline & $\begin{array}{l}\text { Regulatory } \\
\text { concern }\end{array}$ & $\begin{array}{l}\text { Equals to one if a firm has received a regulatory concern from } \\
\text { a regulator and zero otherwise }\end{array}$ & Manual \\
\hline & $\begin{array}{l}\text { Letter of } \\
\text { warning }\end{array}$ & $\begin{array}{l}\text { Equals to one if a firm has received a letter of warning from a } \\
\text { regulator and zero otherwise }\end{array}$ & Manual \\
\hline \multirow{3}{*}{$\begin{array}{l}\text { Test } \\
\text { variables - } \\
\text { Fraud }\end{array}$} & $\begin{array}{l}\text { Recognized } \\
\text { (Reference group) }\end{array}$ & $\begin{array}{l}\text { Equals to one if a firm manipulates its income statements, } \\
\text { balance sheets, cash flows and zero otherwise }\end{array}$ & Manual \\
\hline & $\begin{array}{l}\text { Recognize \& } \\
\text { Disclosed }\end{array}$ & $\begin{array}{l}\text { Equals to one if a firm manipulates its income statements, } \\
\text { balance sheets, cash flows and conceals or untruthfully } \\
\text { discloses information and zero otherwise }\end{array}$ & Manual \\
\hline & Disclosed & $\begin{array}{l}\text { Equals to one if a firm conceals or untruthfully discloses } \\
\text { information in the financial statement and zero otherwise }\end{array}$ & Manual \\
\hline \multirow{9}{*}{$\begin{array}{l}\text { Control } \\
\text { variables }\end{array}$} & Duration & $\begin{array}{l}\text { Calculated from the first fraud year to the last fraud year } \\
\text { reported in the sanction files }\end{array}$ & Manual \\
\hline & Firm size & The natural logarithm of the firm's total assets & CSMAR \\
\hline & $\begin{array}{l}\text { Largest } \\
\text { ownership }\end{array}$ & $\begin{array}{l}\text { The number of shares held by the largest shareholder divided } \\
\text { by the total number of shares outstanding }\end{array}$ & CSMAR \\
\hline & Ownership form & $\begin{array}{l}\text { Equals to one if the nature of the largest shareholder is state- } \\
\text { owned and zero otherwise }\end{array}$ & CSMAR \\
\hline & Institutional & $\begin{array}{l}\text { The number of shares held by institutional investors divided } \\
\text { by the total number of shares outstanding }\end{array}$ & CSMAR \\
\hline & $\begin{array}{l}\text { Chairman } \\
\text { change }\end{array}$ & $\begin{array}{l}\text { Equals to one if a firm experiences chairman turnover and zero } \\
\text { otherwise }\end{array}$ & CSMAR \\
\hline & CEO change & $\begin{array}{l}\text { Equals to one if a firm experiences CEO turnover and zero } \\
\text { otherwise }\end{array}$ & CSMAR \\
\hline & Big ten audit & $\begin{array}{l}\text { Equals to one if a firm is audited by 'Big10' auditors and zero } \\
\text { otherwise }\end{array}$ & CSMAR \\
\hline & CEO ownership & $\begin{array}{l}\text { The number of shares held by the CEO divided by the total } \\
\text { number of shares outstanding }\end{array}$ & CSMAR \\
\hline
\end{tabular}


Chairman and CEO changes and big ten auditors are also added as control variables. The Chairman and CEO variables are consolidated to determine whether investors perceive such changes as a symbolic gesture or a substantive act for a firm to start fresh (Moore, Stuart, \& Pozner, 2010). Moreover, when there is a chairman or CEO change, time is needed to address the fraud and take corrective measures. Therefore, investors are expected to have less confidence in new chairmen and managers leading firms after the announcement of punishments. The big ten auditors are included as these institutions may produce higher quality audits and apply stricter external monitoring, alleviating reputational costs and possible litigation (Chen et al., 2005). Past evidence also suggests fraudulent firms are less likely to hire big external auditors (Ma, Ma, \& Tian, 2016).

Following Aggarwal, Erel, Ferreira and Matos, (2011) this study assumes institutional ownership captures the monitoring function played by the institutional investors. In contrast to U.S. stock markets, corporate ownership is highly concentrated in China with state institutions major block-holders. As state-owned firms are likely to receive greater government financial support and face lower default risks, a positive relationship between the type of shareholders (i.e. firms with state-owned background) and CARs may occur (Chen et al., 2016). Therefore, largest ownership and ownership form are also used as control variables. CEO ownership is also controlled as mangers receiving greater equity-based compensation have substantial discretion in pursuing private interests (Ding, Zhang, \& Zhang, 2007). Except for fraud duration, the control variables are lagged by one year to avoid endogeneity problems. Table 3 summarizes the definition and sources of the variables.

\section{Empirical results}

\subsection{Descriptive statistics}

Table 4 presents descriptive statistics of the variables used. The mean of CARs is $-0.5 \%$ over a 5-day $[-2,2]$ event window and smaller than comparable U.S. findings (Palmrose 
et al., 2004). Rectification notices are the most common punishments, accounting for $53.3 \%$ of the sample. $18.7 \%$ of fraudulent firms have received administrative fines on average. Firms subject to public criticism and condemnation account for $7.4 \%$ and $4.8 \%$ of all listed firms during the sample period, suggesting self-disciplinary measures are applied relatively less frequently. The table also provides statistics of fraud type. Consistent with previous Chinese studies (see Zhu \& Gao 2011), disclosure fraud has the highest incidence and most firms use more than one technique to manipulate financial statements.

\section{Table 4}

Descriptive results. $^{9}$

\begin{tabular}{lcccccc}
\hline \multicolumn{1}{c}{ Variable } & $\mathrm{N}$ & Mean & Median & SD & Kurtosis & Skewness \\
\hline CARs $(-2,2)$ & 433 & -0.005 & -0.007 & 0.057 & 0.215 & 3.910 \\
Warnings & 433 & 0.157 & 0 & 0.364 & 1.885 & 4.554 \\
Criticism & 433 & 0.074 & 0 & 0.262 & 3.257 & 11.611 \\
Condemnation & 433 & 0.048 & 0 & 0.215 & 4.204 & 18.670 \\
FINEs & 433 & 0.187 & 0 & 0.390 & 1.605 & 3.576 \\
Rectification notice & 433 & 0.533 & 1 & 0.499 & -0.134 & 1.018 \\
Regulatory concern & 433 & 0.081 & 0 & 0.273 & 3.076 & 10.459 \\
Letter of warning & 433 & 0.067 & 0 & 0.250 & 3.465 & 13.003 \\
Recognized & 433 & 0.217 & 0 & 0.413 & 1.372 & 2.884 \\
Recognized \& Disclosed & 433 & 0.291 & 0 & 0.455 & 0.920 & 1.847 \\
Disclosed & 433 & 0.485 & 0 & 0.500 & 0.060 & 1.004 \\
Duration & 433 & 1.995 & 1 & 1.915 & 2.625 & 13.909 \\
Firm size & 433 & 21.554 & 21.408 & 1.308 & 0.489 & 3.295 \\
Largest ownership & 433 & 0.328 & 0.307 & 0.146 & 0.516 & 2.932 \\
Ownership form & 433 & 0.210 & 0 & 0.408 & 1.423 & 3.024 \\
Institutional & 433 & 0.045 & 0.017 & 0.086 & 4.134 & 22.492 \\
Chairman change & 433 & 0.187 & 0 & 0.390 & 1.605 & 3.576 \\
CEO change & 433 & 0.219 & 0 & 0.414 & 1.356 & 2.839 \\
Big ten audit & 433 & 0.4 & 0 & 0.490 & 0.410 & 1.168 \\
CEO ownership & 433 & 0.024 & 0 & 0.096 & 4.998 & 31.088 \\
\hline
\end{tabular}

On average, the duration of fraud is 2 years, with the longest fraud being 15 years. The average firm size, based on a firm’s total assets is $\$ 985$ million; institutional investors

${ }^{9}$ Warnings and fines can be imposed either separately or in combination. In particular, firms subject to warnings (only) and fines (only) account for $0.9 \%$ and $3.9 \%$ of total observations. $14.8 \%$ firm-year observations receive the joint-punishment. See Table 7 for additional analysis. 
and CEOs hold $4.5 \%$ and $2.4 \%$ of the shares of fraudulent firms respectively; lower than many other financial markets. Chinese listed firms usually have large controlling shareholders and the largest shareholder on average holds $32.8 \%$ of the total outstanding shares. Moreover, the state is the largest shareholder in $21 \%$ of sample firms. Overall, $18.7 \%$ of and $21.9 \%$ of firms have changed Chairmen and CEOs in the year prior to the fraud announcement. Firms that employ one of the big-ten auditors account for $40 \%$ of the sample.

In an untabulated correlation analysis of the variables, this study finds that warnings are significantly positive correlated with fines, implying regulators use these punishments in combination. The variance inflation factor (VIF) statistics indicate that multicollinearity problems are minimal. ${ }^{10}$

\subsection{Univariate analysis}

Panel A of Table 5 presents the stock market reaction to punishment announcements over a variety of event windows. A large portion of reported CARs are significantly negative, suggesting stock markets view the announcement of sanction decisions negatively. For example, the CARs is $-0.5 \%$ over a 4 -day $[-1,2]$ event window and statistically significant at the 5\% level. In addition, $58.66 \%$ of observations have negative CARs among the full sample. The shareholder wealth loss represents investors' loss of confidence about the firms' future performance, the increase of firm's future costs due to punishments, or the negative reputation generated by the adverse publicity (Chen et al., 2005). In Panel A, CARs range from $-0.2 \%$ to $-0.5 \%$ for the overall sample and are statistically but not economically significant. ${ }^{11}$ This is lower than other Chinese studies (Firth et al. 2009; Wu \& Zhang 2014), where fraud announcements trigger $1 \%$ to $-2 \%$ CARs in short-term event windows, albeit for data which does not

\footnotetext{
10 The values of mean VIF are less than two for the different models. Normality based on skewness and kurtosis is also examined. For non-dummy variables that show substantial departure from normality, robustness checks are conducted in Table 7 (Model 12).

${ }^{11}$ Economic significance is a measure of the importance of a relationship and considers the magnitude of the estimated coefficients (Ziliak and McCloskey, 2013).
} 
incorporate sanction decisions made by CSRC regional offices.

\section{Table 5}

Market reaction to punishments announcements.

\begin{tabular}{|c|c|c|c|c|c|c|c|}
\hline \multicolumn{8}{|c|}{ Panel A CARs around different event windows } \\
\hline Event windows & No. & Coefficient & Std. Err. & t-stat & $\mathrm{P}>|\mathrm{t}|$ & $\%(\mathrm{CAR}<0)$ & Wilcoxon $\mathrm{z}$ \\
\hline$[-5,+5]$ & 433 & -0.004 & 0.004 & -0.91 & 0.362 & $54.965 \%$ & $-4.893 * * *$ \\
\hline$[-3,+3]$ & 433 & -0.002 & 0.003 & -0.48 & 0.633 & $52.887 \%$ & $-2.970 * * *$ \\
\hline$[-2,2]$ & 433 & $-0.005^{*}$ & 0.003 & -1.86 & 0.063 & $56.813 \%$ & $-5.701 * * *$ \\
\hline$[-1,2]$ & 433 & $-0.005 * *$ & 0.002 & -2.13 & 0.033 & $58.661 \%$ & $-6.311 * * *$ \\
\hline$[-1,1]$ & 433 & -0.003 & 0.002 & -1.40 & 0.162 & $57.275 \%$ & $-4.694 * * *$ \\
\hline$[0,2]$ & 433 & $-0.004 *$ & 0.002 & -1.72 & 0.086 & $58.661 \%$ & $-5.150 * * *$ \\
\hline \multicolumn{8}{|c|}{ Panel B Average abnormal return on different event days } \\
\hline Event day & No. & Coefficient & Std. Err. & t-stat & $P>|t|$ & $\%(\mathrm{AR}<0)$ & Wilcoxon z \\
\hline-5 & 433 & $-0.003 * *$ & 0.001 & -2.27 & 0.024 & $58.430 \%$ & $-3.528 * * *$ \\
\hline-4 & 433 & -0.001 & 0.001 & -0.67 & 0.505 & $57.506 \%$ & $-2.006^{* *}$ \\
\hline-3 & 433 & $0.002 * *$ & 0.001 & 2.24 & 0.025 & $50.346 \%$ & 0.851 \\
\hline-2 & 433 & 0.001 & 0.001 & 0.26 & 0.791 & $54.042 \%$ & -0.486 \\
\hline-1 & 433 & -0.001 & 0.001 & -1.17 & 0.242 & $57.737 \%$ & $-2.975 * * *$ \\
\hline 0 & 433 & -0.001 & 0.001 & -0.83 & 0.407 & $56.351 \%$ & $-2.199 * *$ \\
\hline 1 & 433 & -0.001 & 0.001 & -0.59 & 0.557 & $55.427 \%$ & $-1.670^{*}$ \\
\hline 2 & 433 & $-0.002 *$ & 0.001 & -1.81 & 0.070 & $57.044 \%$ & $-2.970 * * *$ \\
\hline 3 & 433 & 0.001 & 0.001 & 0.87 & 0.384 & $52.194 \%$ & -0.268 \\
\hline 4 & 433 & 0.001 & 0.001 & 0.08 & 0.933 & $51.732 \%$ & -0.708 \\
\hline 5 & 433 & 0.001 & 0.001 & 1.01 & 0.315 & $52.194 \%$ & -0.459 \\
\hline \multicolumn{8}{|c|}{ Panel C CARs prior to punishment announcements } \\
\hline Event windows & No. & Coefficient & Std. Err. & t-stat & $P>|t|$ & $\%(\mathrm{CAR}<0)$ & Wilcoxon z \\
\hline$[-15,-6]$ & 433 & $-0.010 * *$ & 0.004 & -2.33 & 0.020 & $57.737 \%$ & $-8.698 * * *$ \\
\hline \multicolumn{8}{|c|}{ Panel D Average abnormal return on different pre-event days } \\
\hline Event day & No. & Coefficient & Std. Err. & t-stat & $P>|t|$ & $\%(\mathrm{AR}<0)$ & Wilcoxon z \\
\hline-15 & 433 & -0.001 & 0.001 & -0.44 & 0.657 & $51.963 \%$ & -1.294 \\
\hline-14 & 433 & -0.001 & 0.001 & -0.69 & 0.493 & $51.501 \%$ & -0.837 \\
\hline-13 & 433 & -0.001 & 0.001 & -1.18 & 0.238 & $57.275 \%$ & $-2.586^{* * *}$ \\
\hline-12 & 433 & -0.001 & 0.001 & -0.04 & 0.972 & $55.196 \%$ & $-1.818^{*}$ \\
\hline-11 & 433 & $-0.002 *$ & 0.001 & -1.65 & 0.099 & $54.734 \%$ & $-2.894 * * *$ \\
\hline-10 & 433 & -0.001 & 0.001 & -0.77 & 0.444 & $55.196 \%$ & $-2.253^{* *}$ \\
\hline-9 & 433 & 0.001 & 0.001 & 0.95 & 0.341 & $51.039 \%$ & 0.217 \\
\hline-8 & 433 & $-0.002 *$ & 0.001 & -1.64 & 0.100 & $55.658 \%$ & $-2.534 * *$ \\
\hline-7 & 433 & -0.001 & 0.001 & -0.65 & 0.517 & $53.811 \%$ & -1.294 \\
\hline-6 & 433 & $-0.003 * *$ & 0.001 & -2.49 & 0.013 & $54.965 \%$ & $-2.373 * *$ \\
\hline
\end{tabular}

Notes: $* * * * *$ and $*$, denote statistical significance at the $1 \%, 5 \%$ and $10 \%$ levels respectively. 
Panel B presents the average abnormal return (AR) around the punishment announcement. The mean AR is $-0.1 \%$ on the announcement day and $56.35 \%$ of observations have negative ARs. Panel C and D pertain to information leakage. Panel C shows statistically significant (5\%) CARs of $-1.0 \%$ over a 10 -day event window $[-15,-6]$. Moreover, $57.74 \%$ observations have negative CARs, suggesting information leakage prior to the announcement of punishment information is widespread. The magnitude of loss in the pre-event window is large and twice as much as the largest loss reported around the punishment announcement. Panel D reports the average abnormal return prior to punishment announcements with a mean AR of $-0.1 \%$ on both event days, -13 and -12 , indicating punishment information begins to leak to the market almost 1213 days prior to its official announcement. ${ }^{12}$

\subsection{Multivariate analysis}

Model 1 of Table 6 produces findings consistent with hypothesis 1, i.e. fines are associated with more negative stock market reaction than other 'name and shame' nonmonetary punishments. This result indicates that investors perceive monetary penalties more severely than non-monetary penalties, which is in line with findings from Kurz et al. (2014), and Killias, Villettaz and Nunweiler-Hardegger (2016). Although nonmonetary punishments can trigger reputational losses, these punishments are not a sign of severe offences and their costs are limited. Subsequently, monetary punishments speak more loudly.

Model 2 examines hypothesis 2. A significant and negative coefficient of -0.043 is reported for recognition and disclosure fraud and a non-significant coefficient is estimated for disclosure fraud. Consistent with hypothesis 2, investors perceive

\footnotetext{
12 Apart from parametric t-tests, a nonparametric test: Wilcoxon Signed-rank test is also applied. The test bears null hypothesis of an equal number of positive and negative cumulative abnormal returns for a given event window under the framework of binominal test. The Wilcoxon Signed-rank test considers both the sign and magnitude of abnormal returns and does not assume normality or infer the value of any population parameter (Huang, 2013). The Wilcoxon Z-statistics for all CARs over different event windows and ARs on event day -13, $12,-11,-10,-8,-6,-5,-4,-1,0,1,2$ are significant in Table 5.4, implying the rejection of null hypothesis and the results are not driven by the outliers (Modi, Wiles, \& Mishra, 2015).
} 
manipulation of both recognized and disclosed information more severely than false disclosed information. This result supports Israeli (2015) and Michels (2017)'s finding that investors place smaller valuation weights on disclosed events and underreact to these events due to higher processing costs.

As information leakage is indicated, informed investors may transact to garner profits. CARs $[-15,-6]$ are then used as the dependent variable to re-estimate the previous models and test the hypothesis 3. As shown in Model 3, monetary fines are negatively and statistically significant related to CARs. However, non-monetary penalties have no significant impact on stock market reaction, consistent with hypothesis 3 . This implies informed investors with private information perceive monetary penalties more severely than the non-monetary penalties. Compared to the magnitude of stock market reaction between pre-event and event periods, the negative market reaction to fines is significantly stronger in $[-15,-6]$ pre-event period $(-13.4 \%)$ than the $[-2,2]$ event period $(-6.0 \%)$. Monetary penalties have therefore resulted in greater shareholder wealth losses prior to punishment announcements, and at the formal announcement stage, the investor loss is lower. Model 4 reports insignificant coefficients of fraud variables, which suggest that informed investors are not sensitive to specific fraudulent behaviours.

Turning to the control variables in Models 1-4, the largest ownership form is positive and significantly related to CARs. This is because investors perceive the post-fraud performance of the state-owned firms to be more likely to recover and less likely to deteriorate (Chen et al., 2016). The coefficients for big ten auditors are positive and statistically different from zero in Models 1 and 3. The result implies that if a firm is audited by one of the big ten auditors, a reduced negative market reaction to fraud announcement is experienced. This is because investors perceive big audit firms have motivation to provide stricter external monitoring to avoid ruining reputation (Yang, Jiao, \& Buckland, 2017). CEO ownership is significantly negative related to market reaction, consistent with the result in Ali and Zhang (2015). Higher stock ownership creates greater motivation for CEOs to overstate earnings, which results in a significant loss of public confidence. 
Table 6

Regression results.

\begin{tabular}{|c|c|c|c|c|c|c|}
\hline $\begin{array}{l}\text { Variables } \\
\text { Event window }\end{array}$ & $\begin{array}{c}\text { Model } 1 \\
{[-2,2]}\end{array}$ & $\begin{array}{c}\text { Model } 2 \\
{[-2,2]}\end{array}$ & $\begin{array}{l}\text { Model } 3 \\
{[-15,-6]}\end{array}$ & $\begin{array}{l}\text { Model } 4 \\
{[-15,-6]}\end{array}$ & $\begin{array}{l}\text { Model } 5 \\
{[-13,-6]}\end{array}$ & $\begin{array}{l}\text { Model } 6 \\
{[-12,-6]}\end{array}$ \\
\hline Criticism & $\begin{array}{l}-0.036 \\
(0.027)\end{array}$ & & $\begin{array}{c}0.032 \\
(0.032)\end{array}$ & & $\begin{array}{l}-0.019 \\
(0.027)\end{array}$ & $\begin{array}{l}-0.035 \\
(0.023)\end{array}$ \\
\hline Condemnation & $\begin{array}{l}-0.039 * \\
(0.021)\end{array}$ & & $\begin{array}{l}-0.052 \\
(0.038)\end{array}$ & & $\begin{array}{c}-0.072 * * \\
(0.034)\end{array}$ & $\begin{array}{l}-0.057 * \\
(0.031)\end{array}$ \\
\hline Fines & $\begin{array}{l}-0.060 * \\
(0.032)\end{array}$ & & $\begin{array}{c}-0.134 * * * \\
(0.051)\end{array}$ & & $\begin{array}{c}-0.122 * * * \\
(0.039)\end{array}$ & $\begin{array}{c}-0.105 * * * \\
(0.038)\end{array}$ \\
\hline Rectification notice & $\begin{array}{c}-0.059 * * * \\
(0.020)\end{array}$ & & $\begin{array}{l}-0.004 \\
(0.022)\end{array}$ & & $\begin{array}{l}-0.004 \\
(0.021)\end{array}$ & $\begin{array}{l}-0.006 \\
(0.017)\end{array}$ \\
\hline Regulatory concern & $\begin{array}{l}-0.047 * \\
(0.026)\end{array}$ & & $\begin{array}{c}0.026 \\
(0.038)\end{array}$ & & $\begin{array}{c}0.008 \\
(0.039)\end{array}$ & $\begin{array}{c}0.004 \\
(0.036)\end{array}$ \\
\hline Letter of warning & $\begin{array}{l}-0.025 \\
(0.026)\end{array}$ & & $\begin{array}{l}-0.051 \\
(0.040)\end{array}$ & & $\begin{array}{l}-0.061 * \\
(0.033)\end{array}$ & $\begin{array}{c}-0.062 * * \\
(0.026)\end{array}$ \\
\hline Disclosed & & $\begin{array}{l}-0.006 \\
(0.020)\end{array}$ & & $\begin{array}{c}0.004 \\
(0.027)\end{array}$ & & \\
\hline Recognized \& Disclosed & & $\begin{array}{c}-0.043 * * \\
(0.020)\end{array}$ & & $\begin{array}{l}-0.060 \\
(0.036)\end{array}$ & & \\
\hline Duration & $\begin{array}{c}0.001 \\
(0.004)\end{array}$ & $\begin{array}{c}0.005 \\
(0.004)\end{array}$ & $\begin{array}{c}0.003 \\
(0.004)\end{array}$ & $\begin{array}{c}0.007 \\
(0.005)\end{array}$ & $\begin{array}{c}0.005 \\
(0.004)\end{array}$ & $\begin{array}{c}0.005 \\
(0.004)\end{array}$ \\
\hline Firm size & $\begin{array}{l}-0.008 \\
(0.006)\end{array}$ & $\begin{array}{l}-0.005 \\
(0.008)\end{array}$ & $\begin{array}{l}-0.002 \\
(0.014)\end{array}$ & $\begin{array}{c}0.009 \\
(0.015)\end{array}$ & $\begin{array}{c}0.001 \\
(0.014)\end{array}$ & $\begin{array}{c}0.005 \\
(0.014)\end{array}$ \\
\hline Largest ownership & $\begin{array}{c}0.105 \\
(0.111)\end{array}$ & $\begin{array}{c}0.028 \\
(0.123)\end{array}$ & $\begin{array}{c}0.194 \\
(0.338)\end{array}$ & $\begin{array}{l}-0.005 \\
(0.253)\end{array}$ & $\begin{array}{c}0.223 \\
(0.257)\end{array}$ & $\begin{array}{c}0.133 \\
(0.231)\end{array}$ \\
\hline Ownership form & $\begin{array}{c}0.078 * * * \\
(0.019)\end{array}$ & $\begin{array}{c}0.065 * * * \\
(0.019)\end{array}$ & $\begin{array}{c}0.003 \\
(0.033)\end{array}$ & $\begin{array}{l}-0.002 \\
(0.035)\end{array}$ & $\begin{array}{l}-0.004 \\
(0.036)\end{array}$ & $\begin{array}{l}-0.003 \\
(0.033)\end{array}$ \\
\hline Institutional ownership & $\begin{array}{c}0.181 \\
(0.276)\end{array}$ & $\begin{array}{c}0.045 \\
(0.319)\end{array}$ & $\begin{array}{l}-0.045 \\
(0.383)\end{array}$ & $\begin{array}{l}-0.123 \\
(0.338)\end{array}$ & $\begin{array}{l}-0.110 \\
(0.393)\end{array}$ & $\begin{array}{c}-0.083 \\
(0.329)\end{array}$ \\
\hline Chairman change & $\begin{array}{l}-0.023 \\
(0.020)\end{array}$ & $\begin{array}{l}-0.021 \\
(0.020)\end{array}$ & $\begin{array}{l}-0.015 \\
(0.022)\end{array}$ & $\begin{array}{l}-0.019 \\
(0.028)\end{array}$ & $\begin{array}{l}-0.027 \\
(0.023)\end{array}$ & $\begin{array}{l}-0.017 \\
(0.020)\end{array}$ \\
\hline CEO change & $\begin{array}{c}-0.001 \\
(0.020)\end{array}$ & $\begin{array}{l}-0.019 \\
(0.023)\end{array}$ & $\begin{array}{c}0.004 \\
(0.025)\end{array}$ & $\begin{array}{l}-0.015 \\
(0.024)\end{array}$ & $\begin{array}{c}0.016 \\
(0.023)\end{array}$ & $\begin{array}{c}0.001 \\
(0.019)\end{array}$ \\
\hline Big ten audit & $\begin{array}{c}0.061 * * \\
(0.026)\end{array}$ & $\begin{array}{c}0.089 * * * \\
(0.028)\end{array}$ & $\begin{array}{l}-0.015 \\
(0.034)\end{array}$ & $\begin{array}{c}0.023 \\
(0.042)\end{array}$ & $\begin{array}{l}-0.036 \\
(0.031)\end{array}$ & $\begin{array}{l}-0.048 * \\
(0.028)\end{array}$ \\
\hline CEO ownership & $\begin{array}{c}-0.263^{* * * *} \\
(0.051)\end{array}$ & $\begin{array}{c}-0.218^{* * *} \\
(0.064)\end{array}$ & $\begin{array}{l}-0.021 \\
(0.107)\end{array}$ & $\begin{array}{l}-0.071 \\
(0.115)\end{array}$ & $\begin{array}{l}-0.084 \\
(0.105)\end{array}$ & $\begin{array}{l}-0.029 \\
(0.068)\end{array}$ \\
\hline Constant & $\begin{array}{c}0.133 \\
(0.142)\end{array}$ & $\begin{array}{c}0.069 \\
(0.174)\end{array}$ & $\begin{array}{l}-0.014 \\
(0.268)\end{array}$ & $\begin{array}{l}-0.201 \\
(0.299)\end{array}$ & $\begin{array}{l}-0.077 \\
(0.269)\end{array}$ & $\begin{array}{l}-0.117 \\
(0.276)\end{array}$ \\
\hline Observations & 433 & 433 & 433 & 433 & 433 & 433 \\
\hline R-squared & 0.328 & 0.250 & 0.080 & 0.073 & 0.126 & 0.127 \\
\hline F-statistics & $6.08 * * *$ & $3.88 * * *$ & $5.42 * * *$ & 0.58 & $18.93 * * *$ & $5.14 * * *$ \\
\hline Firm fixed effects & Yes & Yes & Yes & Yes & Yes & Yes \\
\hline
\end{tabular}

Notes: All of the variables are defined in the Table 3. ***, ** and *, denote statistical significance at the $1 \%, 5 \%$ and $10 \%$ levels. The dependent variable is CARs over a [-2, 2] event window in the Models 1 and 2, and over a $[-15,-6]$ pre-event window in the Models 3 and 4, and over [-13, -6] [-12, -6] pre-event windows in Models 5 and 6. Firm fixed effects are controlled. 
The 'name and shame' non-monetary punishments can be divided into two groups, including supervisory and self-disciplinary measures. ${ }^{13}$ With respect to supervisory measures, there is a significant and negative relationship between rectification notice, regulatory concern and CARs over a $[-2,2]$ event window in the Model 1 . However, non-significant coefficients of three supervisory measures are reported in the Model 3 by estimating CARs over a $[-15,-6]$ pre-event window. This section re-runs the model by selecting CARs over shorter and concentrated pre-event windows [-13, -6$]$ and $[-12$, -6]. ${ }^{14}$ This is because a shorter pre-event window can better capture the potential information leakage of punishments, as it isolates the impact of other events that can occur within the same window (Basdas \& Oran, 2014).

The results are presented in Models 5-6. It is reported that the letter of warning has a significant and negative impact on CARs, while coefficients for rectification notice and regulatory concern are non-significant. This implies informed investors with private information perceive a letter of warning more severely than other supervisory measures. It is also reported that regulatory concern is the least severe supervisory punishment, as evidenced by the sign and magnitude of coefficients. These findings are in line with related guidance specified in the CSRC's regulatory manual, in which the CSRC regional offices are instructed to issue statements of regulatory concern when there are general problems detected during the inspection of a firm's financial statements. For more severe problems, they are instructed to issue letters of warning or rectification notices or adopt other supervisory measures (CSRC, 2012).

In terms of self-disciplinary measures, the coefficients of public criticism are not significant, which indicates the capital market views them as non-severe punishments. Public condemnation is a severe punishment relative to public criticism, as evidenced by the significant and negative coefficient of public condemnation over both event

\footnotetext{
${ }^{13}$ Punishments involving administrative warnings are selected as the reference group.

14 This section chooses -13 and -12 as the beginning pre-event date because punishment information starts to leak to capital market 12-13 days prior to the formal regulatory announcements based on Wilcoxon Signed-rank tests.
} 
windows and pre-event windows. This is consistent with Firth et al. (2016)'s argument that public condemnation should be used to punish relatively severe offences.

These results indicate that although a few non-monetary punishments, such as public condemnation and letters of warning carry reputational losses to the fraudulent firms during the pre-event period, the costs are relatively limited. If the managers can manage the punishment information disclosure and firms' stock prices can quickly absorb leaked information in the capital markets, the reputational costs are moderated following the regulatory announcements. Subsequently, the coefficients of these nonmonetary punishments are significant and negative in the pre-event period, but become either economically or statistically insignificant after fraud events are announced. On the other hand, monetary punishments carry far greater reputational costs to the fraudulent firms in both pre-event period and event period, as evidenced by the magnitude and sign of coefficients of fines. As a result, monetary punishments are less affected by information leakage and are more effective in addressing accounting fraud.

\subsection{Robustness tests}

The results of additional robustness tests are reported as follows. First, this section reestimates the previous models by using a broader classification of non-monetary punishments. In other words, variables i.e. rectification notice, regulatory concern and letter of warning are replaced with a dummy variable 'supervisory measures', and variables i.e. public criticism and condemnation are replaced with another dummy variable 'self-measures'. The findings are presented in Panel A of Table 7, which confirm fines result in a more negative stock market reaction than non-monetary punishments. 
Table 7

Robustness tests.

\begin{tabular}{lcc}
\hline Panel A: Broader classification of punishments & & \\
\hline Variables & {$[-2,2]$ CARs } & {$[-15,-6]$ CARs } \\
Fines & $-0.059^{*}$ & $-0.133^{* *}$ \\
Supervisory measures & $-0.059 * * *$ & -0.009 \\
Self-measures & $-0.037 * *$ & 0.012 \\
Control variables & Yes & Yes \\
Firm fixed effects & Yes & Yes \\
Observations & 433 & 433 \\
R-squared & 0.325 & 0.036 \\
F-statistics & $5.42 * * *$ & $4.04 * * *$ \\
\hline
\end{tabular}

Panel B: The size of fines and stock market reaction

\begin{tabular}{lcc}
\hline Variables & {$[-2,2]$ CARs } & {$[-15,-6]$ CARs } \\
Fines level & $-0.005^{*}$ & $-0.011^{* *}$ \\
Control variables & Yes & Yes \\
Firm fixed effects & Yes & Yes \\
Observations & 433 & 433 \\
R-squared & 0.324 & 0.035 \\
F-statistics & $5.41 * * *$ & $1.98 * *$
\end{tabular}

Panel C: Fines and warnings imposed simultaneously

\begin{tabular}{lcc}
\hline Variables & {$[-2,2]$ CARs } & {$[-15,-6]$ CARs } \\
Fines level & $-0.011^{*}$ & $-0.019^{*}$ \\
Fines level \& Warn & $-0.006^{*}$ & -0.007 \\
Control variables & Yes & Yes \\
Firm fixed effects & Yes & Yes \\
Observations & 433 & 433 \\
R-squared & 0.331 & 0.039 \\
F-statistics & $5.88 * * *$ & $3.23 * * *$ \\
\hline Panel D: Individual-level punishments & & {$[-15,-6]$ CARs } \\
\hline Variables & {$[-2,2]$ CARs } & $-0.132^{* *}$ \\
Fines & $-0.066^{*}$ & $-0.115^{* *}$ \\
Individual & -0.124 & Yes \\
Control variables & Yes & Yes \\
Firm fixed effects & Yes & 451 \\
Observations & 451 & 0.123 \\
R-squared & 0.303 & $3.15^{* * *}$ \\
F-statistics & $7.30 * * *$ & \\
\hline
\end{tabular}

Notes: All of the variables are defined in the Table 3. ***, ** and *, denote statistical significance at the $1 \%, 5 \%$ and $10 \%$ levels. Supervisory measures equal to one if a firm has received rectification notice, regulatory concern or letter of warning from a regulator and zero otherwise. Self-measures equal to one if a firm has received criticism or condemnation from a regulator and zero otherwise. Fines level equals to the natural logarithm of one plus the amounts of fines if a firm only subjects to fines. Fines level \& Warn equals to the natural logarithm of one plus the amounts of fines if a firm subjects to both warning and fines. Individual punishments equal to one if a firm commits fraud but only relevant individuals are punished and zero otherwise. Firm fixed effects are controlled. 
Table 7

Robustness tests (continued).

\begin{tabular}{|c|c|c|}
\hline \multicolumn{3}{|c|}{ Panel E: Two stage least squares method regression results } \\
\hline Variables & $\begin{array}{c}\text { First stage } \\
\text { Fines }\end{array}$ & $\begin{array}{l}\text { Second stage } \\
\text { CARs }[-2,2]\end{array}$ \\
\hline STATE & $0.117 * * *$ & \\
\hline SUP & $-0.227 * * *$ & \\
\hline Fines 1 & & $-1.234 * * *$ \\
\hline Control variables \& Firm fixed effects & Yes & Yes \\
\hline Observations & 451 & 451 \\
\hline Wald $\mathrm{Chi}^{2}$ & & $34.20 * *$ \\
\hline F statistic, instrument relevance & & $12.84 * * *$ \\
\hline Sargan-Hansen statistic (P-value) & & $0.343(0.558)$ \\
\hline Hausman test $\mathrm{Chi}^{2}$ (P-value) & & $6.42(0.989)$ \\
\hline \multicolumn{3}{|c|}{ Panel F: Calculating CARs using the market model } \\
\hline Variables & {$[-2,2]$ CARs } & {$[-15,-6]$ CARs } \\
\hline Fines & $-0.060^{*}$ & $-0.134 * * *$ \\
\hline Control variables \& Firm fixed effects & Yes & Yes \\
\hline Observations & 433 & 433 \\
\hline R-squared & 0.328 & 0.080 \\
\hline F-statistics & $6.07 * * *$ & $5.51 * * *$ \\
\hline \multicolumn{3}{|l|}{ Panel G: Modified dependent variables } \\
\hline Variables & {$[0,1]$ CARs } & {$[0,2]$ CARs } \\
\hline Fines & $-0.041 * *$ & $-0.055^{*}$ \\
\hline Control variables \& Firm fixed effects & Yes & Yes \\
\hline Observations & 433 & 433 \\
\hline R-squared & 0.261 & 0.324 \\
\hline F-statistics & $4.04 * * *$ & $4.40 * * *$ \\
\hline \multicolumn{3}{|l|}{ Panel H: Addressing normality concerns } \\
\hline Variables & {$[-2,2]$ CARs } & {$[-15,-6]$ CARs } \\
\hline Fines & $-0.060 *$ & $-0.148 * *$ \\
\hline Control variables \& Firm fixed effects & Yes & Yes \\
\hline Observations & 433 & 433 \\
\hline R-squared & 0.326 & 0.070 \\
\hline F-statistics & $4.13 * * *$ & $6.13 * * *$ \\
\hline \multicolumn{3}{|l|}{ Panel I: Difference-in-differences model } \\
\hline Variables & & {$[-2,2]$ CARs } \\
\hline Non-Fines*Post & & $-0.035^{* *}$ \\
\hline Control variables & & Yes \\
\hline Observations & & 433 \\
\hline R-squared & & 0.132 \\
\hline F-statistics & & $1.72 * * *$ \\
\hline
\end{tabular}

Notes:STATE is coded 1 if state owners have invested in a listed firm and zero otherwise. SUP is coded 1 if the number of supervisors in a listed firm is above the sample mean and zero otherwise. Fines 1 is the predicted value of endogenous variable. Non-FINEs is coded one if a firm subjects to a non-monetary punishment and zero otherwise. Post is coded one if a punishment was made after the anti-corruption campaign started and zero otherwise. The remaining variables are as defined in the Table 3. ${ }^{* *}, * *$ and $*$, denote statistical significance at the $1 \%, 5 \%$ and $10 \%$ levels. CARs, duration, firm size, largest ownership, institutional ownership and CEO ownership are transformed by taking natural logarithms in Panel H. Panel I uses a difference-in-differences model and controls industry and year effects. 
Second, a few studies have assessed the relationship between the size of fines and the magnitude of investor losses. For instance, Karpoff et al. (2007) find that both private and regulatory monetary penalties are positively and significantly related to the measures of investors' potential losses resulting from corporate misconduct in U.S. However, the non-monetary punishments are unrelated to the magnitude of the investor harm. ${ }^{15}$ This section estimates the association between the magnitude of fines and associated drops in stock market reaction by replacing the dummy variable 'fines' into the continuous variable 'Fines level' (i.e. natural logarithm of one plus the amounts of fines if a firm only subjects to fines).

It is reported that there is a significant and negative relationship between the magnitude of fines and CARs in both $[-2,2]$ and $[-15,-6]$ event windows (see Panel B). In other words, the larger the fine, the greater the fall in firm value. However, this finding needs to be interpreted with caution. In particular, under securities law the maximum fines imposed by the CSRC for corporate misrepresentation are 600,000 Yuan (about $\$ 90,000)$. Subsequently, no general conclusion whether regulators should impose higher fines on perpetrators to produce stronger retributive effect' should be drawn, as the variable 'Fines level' is censored in the regression model.

Third, as fines and warnings can be imposed simultaneously, this section re-estimates the stock market reaction to different punishments by taking the joint-punishment into consideration. An indicator variable (Fines level \& Warn) is constructed, which equals the natural logarithm of one plus the amounts of fines if firms subject to both fines and warnings. Panel $\mathrm{C}$ presents the estimation results over $[-2,2]$ and $[-15,-6]$ event windows. It is reported that 'Fines level' is associated with more negative stock market reaction than 'Fines level \& Warn'. This implies that the existence of warnings dilutes

\footnotetext{
15 Investor harm in Karpoff et al. (2007)'s paper is measured through a series of variables, including provable loss (a firm's highest market value minus its value at the close of trading of the day after the enforcement event), public float (the percentage of a firm's shares not owned by officers, directors or majority owners), violation period stock price run-up (CARs calculated over the violation period using value-weighted index of all stocks), insider trading dummy and fraud dummy (dichotomous variables that take a value of 1 if insider trading/fraud charges are included in regulatory proceedings and 0 otherwise).
} 
the retributive effect of fines in addressing accounting fraud.

Fourth, for firms committing accounting fraud, the Chinese regulatory institutions can punish both firms and individuals, but in some cases, they punish either the firms or the individuals, not both parties. Subsequently, this section re-estimates the regression model by including 18 cases where only the fraudulent individuals are punished. An indicator variable (individual punishments) is created and coded one if individuals rather than firms are punished and zero otherwise. The results are presented in the Panel $\mathrm{D}$ of Table 7. It is observed that cases receiving individual-level punishments are negatively associated with CARs over a $[-15,-6]$ pre-event window. However, the coefficient of individual punishments becomes non-significant over a $[-2,2]$ event window as the related reputational costs have been moderated by information leakage. It is important to notice that regulatory fines trigger more negative stock market reaction than the firms receiving no firm-level punishment, which is consistent with previous main findings.

Fifth, endogeneity concerns are addressed in this section. Endogeneity may arise between fines and stock market reaction, as fines affect stock market reactions and the latter might influence the former. Chen et al. (2011) propose that when making decisions about punishments, the CSRC considers several factors including investors losses, where the greater the investor losses, the greater possibility of firms being subject to heavy penalties. If this is the case, the regression model may produce biased and inconsistent estimates. This issue is addressed by instrumenting the fines measure as well as re-estimating the fixed-effects regression model for CARs using two-stage least squares (2-SLS) method. A Generalised Method of Moments (GMM) model is not adopted as it requires the use of lagged dependent variables as explanatory variables. A lagged dependent variable refers to the stock market reaction to a random event ahead of the announcement of fraud, which does not have any economic meaning in this study. Two instrumental variables used for fines are 'STATE' and 'SUP'. STATE is coded 1 if state owners have invested in a listed firm and zero otherwise. For firms with investments from state or state agencies, they are more likely to carry out social 
objectives with a negative impact on firm value (Wu, Wu, \& Rui, 2012). Subsequently, these firms tend to commit more severe fraud, resulting in higher likelihood of fines. SUP is coded 1 if the number of supervisors in a listed firm is above the sample mean and zero otherwise. Large supervisory board size implies improved oversight and vigilance, leading to less severe punishments imposed on firms (Jia, Ding, $\mathrm{Li}$, \& Wu, 2009). The appropriate instrumental variables must be correlated with the endogenous variable (Fines) but not correlated with the error term ( $\mathrm{Su}, 2015)$.

The 2-SLS method initially uses the endogenous variable (Fines) to regress the instrumental variables (STATE and SUP) and other exogenous covariates; the predicted value of endogenous variable (Fines1) can then be calculated. In the second stage, the predicted value of Fines1 replaces the observed value of Fines in the main regression equation to obtain the estimated coefficients. As Fines1 is a linear function of exogenous covariates and instrumental variables only, by construction there is zero covariance between Fines 1 and the disturbance term $\varepsilon_{i t}$ (Jaafar \& El-Shawa, 2009).

Panel E of Table 7 reports the 2-SLS estimation results. In the first stage, the STATE and SUP are significantly related to Fines at 1\% level. The F-statistic for testing instrument relevance exceeds ten, supporting the strength of the instrumental variables. ${ }^{16}$ The Sargan-Hansen statistic for testing instrument exogeneity signifies that instrumental variables are jointly exogenous (Elyasiani \& Zhang, 2015). ${ }^{17}$ The second stage coefficient estimates identify the effectiveness of punishments by studying stock market reaction. It is reported that Fines1 is related to more negative stock market reaction than other punishments, implying fines trigger the most severe investor losses. A Hausman test is conducted to examine the differences of coefficient estimates between fixed effects model and 2-SLS fixed effects model and confirms differences

\footnotetext{
16 Staiger and Stock (1997) suggest that the F-statistic should exceed ten to demonstrate instrument relevance. It is reported that F-statistic equals to 12.84 in this research, implying instrumental variable is useful in explaining the variation in the endogenous covariate.

17 The specific Sargan-Hansen statistic can be undertaken in the overidentifying cases when the number of instruments exceeds the number of endogenous variables. The null hypothesis for the Sargan-Hansen statistic is that all instruments are exogenous. The result cannot reject the null hypothesis and it is concluded that all the instruments are uncorrelated with the error term.
} 
between two estimators are statistically insignificant.

Sixth, the regression model is re-estimated by calculating CARs through the market model. Market model reflects a linear relationship between individual stock returns and the benchmark market returns. The findings (Panel F) are qualitatively identical as those reported in the Table 6 . This section also modifies the event window of dependent variable CARs to a 2 -day post-event window $[0,1]$ and a 3 -day post-event window $[0$, 2] and re-examines the relationship between CARs and punishments. It is reported that investors perceive fines more severely than non-monetary punishments (see Panel G of Table 7). Moreover, normality concern is addressed. Results of standard tests on skewness and kurtosis indicate a problem with the normality assumption. Hence, for non-dummy variables show substantial departure from normality, this section transforms the data by taking natural logarithms. ${ }^{18}$ The results are presented in Panel $\mathrm{H}$ and it is reported that the main findings are qualitatively similar.

Seventh, this section uses a difference-in-differences (DID) model and examines the impact of punishments on stock market reaction following the start of anti-corruption campaign. President Xi Jinping officially took office in the $18^{\text {th }}$ National Congress of the Communist Party of China on the 14th November 2012. Shortly after his assumption of the presidency of the party, the party promulgated eight provisions and corrected 'four winds' to regulate the party members, which signals the beginning of the anti-corruption campaign (Zhang, 2018). ${ }^{19}$

To run a DID model, this section creates a variable Non-Fines (treatment firms), which equals to one if a firm receives a non-monetary punishment and zero otherwise; and a variable Post, which equals one to if a firm was punished in the post anti-corruption

\footnotetext{
${ }^{18}$ For variables with an absolute skew value larger than 2 or an absolute kurtosis larger than 7 , they can be considered as having substantial non-normality (Kim, 2013). In Model 14, CARs, duration, firm size, largest ownership, institutional ownership and CEO ownership are transformed by taking natural logarithms.

19 According to the official record of the Central Commission for Discipline Inspection, more than 40 central and local officials had been investigated during the anti-corruption campaign by the end of 2014. However, only 6-8 central or local officials had been investigated each year prior to the anti-corruption campaign.
} 
campaign period and zero otherwise. The variable of interest in the regression model is the coefficient of the interaction term (Non-Fines*Post), which captures the impact of non-monetary punishments on stock market reaction in the anti-corruption campaign period. Panel I presents the results and it shows a significant and negative coefficient on the interaction term. The results suggest that, relative to the firms receive fines, firms subject to non-monetary punishments experience a significant decrease in stock market reaction subsequent to the start of anti-corruption campaign.

\section{Conclusions}

In this study the effectiveness of different monetary and non-monetary 'name and shame' punishments for accounting fraud are assessed. This is undertaken through examining the stock market reaction to the regulatory reporting of such crimes in China from 2007 to 2016. Overall, punishment has a significant impact on the market value of fraudulent firms. The magnitude of the investor losses ranges from $-0.2 \%$ to $-0.5 \%$, indicating a statistically but not economically significant impact on fraudulent firms. This value is lower than previous Chinese studies which have not incorporated regional office announcements.

Using a regression model, this study estimates investors perceive punishments involving monetary penalties more severely than those without monetary penalties. This result occurs as monetary penalties not only result in direct cash outflows yet lose reputation for fraudulent firms. Monetary penalties indeed speak very loudly in China and enforcement in severe fraud cases may need to use fines liberally and be aware of the limitations of non-monetary 'name and shame' punishments. Stock markets can also discriminate among different fraudulent behaviours and react less significantly to the disclosure than the combination of disclosure and recognition fraud. This may arise from different perceptions of recognized and disclosed items, leading investors to value false recognition of items more than false disclosure of items. This study also finds information leakage prior to the announcement of punishments. Informed investors with such private information perceive monetary penalties more severely than the nonmonetary penalties; results which remain robust after conducting additional analysis. 
The findings of this study offer important theoretical and practical implications for improving the effectiveness of punishments in addressing accounting fraud. First, meaningful monetary penalties play an important role in forming a strong enforcement program. This result may arise from the imperfect legal environment and unique ownership structure in China, which encourages investors to perceive fines have retributive effects and produce sufficient disutility to outweigh gains from fraud. The paper acknowledges that there are limitations of financial penalties, such as the use of fines primarily hits shareholders who have no direct responsibilities for fraud. The U.S. SEC has not been shy about promoting its use of monetary penalties in last decade, but the SEC is facing increased criticism for heavy reliance on fines as they are not always sufficient and can send the wrong signal to market participants (Steinway, 2014). Therefore, although monetary penalties shout very loudly in Chinese capital markets, they need to be used with caution. The CSRC should not always impose monetary sanctions against corporations, and when it does, it should tie the amount to the gains generated by fraudulent behaviours.

Second, as investors view punishments for different types of fraud distinctly, more strict disclosure regulations associated with financial reporting are needed. Further, when a disclosure fraud is deemed to be serious, especially in relation to false disclosure of material related party transactions, investment status, accounting policies and guaranteed items (Zhu \& Gao, 2011), harsher punishments need to be imposed and fully enforced even if investors react less negatively. In doing so, regulators can increase the costs of disclosure fraud and help investors understand the value to comprehending a firm's disclosed items.

Third, information leakage prior to formal punishment announcements is observed. To keep corporate insiders and other informed investors from trading on non-public information and prevent information leakage, regulatory gaps in China's Securities Laws need to be addressed. In particular, China's Securities Law only addresses the cases regarding traders using leaked information to make profits, yet not traders using leaked information to avoid losses (Weng \& Jia, 2015). Moreover, selective 
enforcement of regulations in China may amplify the level of information asymmetry between informed insiders and outside investors (Chen et al., 2011). Therefore, regulators need to fully enforce regulations and revise the Securities Law to avoid such loopholes for informed investors to profit from non-public material information.

Our study has two limitations, which provide avenues for future research. First, this study focuses on the impact of punishment announcement on the short-term stock returns. The longer-term economic consequences caused by financial statement fraud are still unknown to investors. Hitz et al. (2012) argue that the stock market needs several days to fully react to punishment news, as the lack of experience interpreting enforcement measures precludes investors from comprehending the punishment announcements' implications in the short-term. Tibbs et al. (2011) find the negative abnormal returns reach a trough around the third year after the disclosure of corporate misconduct. Therefore, future research is expected to direct its attention to the longterm implications of punishment announcements for shareholder wealth.

Second, this study only examines the impact of different punishments on shareholder valuation of listed firms. Future studies can go beyond examining investors' stock market reaction and focus on how the disclosure of fraud affects firms' different stakeholders' activities when studying the economic consequences of fraud. For instance, suppliers are expected to change the terms of trade with which they do business with the firms (Karpoff et al., 2008). Banks tend to grant loans with significantly higher spreads, shorter maturities, more covenant restrictions and a higher likelihood of being secured to fraud firms (Graham et al., 2008). Customers may be apprehensive in dealing with firms that have a dishonest management, reducing the demand for the fraud firm's products (Johnson et al., 2014). As different stakeholders are heterogeneous and affected by firms' activities to a different extent, more attention should be paid to their reaction to Chinese accounting fraud in future research. 


\section{References}

Aggarwal, R., Erel, I., Ferreira, M., \& Matos, P. (2011). Does governance travel around the world? evidence from institutional investors. Journal of Financial Economics, 100(1), 154-181.

Aggarwal, R., Hu, M., \& Yang, J. (2015). Fraud, market reaction, and role of institutional investors in Chinese listed firms. The Journal of Portfolio Management, 41(5), 92-109.

Agrawal, A., \& Cooper, T. (2015). Insider trading before accounting scandals. Journal of Corporate Finance, 34, 169-190.

Aguzzoni, L., Langus, G., \& Motta, M. (2013). The effect of EU antitrust investigations and fines on a firm's valuation. The Journal of Industrial Economics, 61(2), 290-338.

Ali, A., \& Zhang, W. (2015). CEO tenure and earnings management. Journal of Accounting and Economics, 59(1), 60-79.

Amel-Zadeh, A., \& Faasse, J. (2016). The information content of 10-K narratives: Comparing MD\&A and footnotes disclosures. Available at SSRN: $\underline{\text { Htps://ssrn.com/abstract=2807546. }}$

Anagnostopoulou, S. C., \& Tsekrekos, A. E. (2015). Earnings management in firms seeking to be acquired. The British Accounting Review, 47(4), 351-375.

Anderson, K. L., \& Yohn, T. L. (2002). The effect of 10K restatements on firm value, information asymmetries, and investors' reliance on earnings. Available at SSRN: Https://ssrn.com/abstract=332380.

Armour, J., Mayer, C., \& Polo, A. (2017). Regulatory sanctions and reputational damage in financial markets. Journal of Financial and Quantitative Analysis, 52(4), 1429-1448.

Ashton, J. K., \& Hudson, R. S. (2014). Do lenders cross-subsidise loans by selling payment protection insurance? International Journal of the Economics of Business, 21(1), 121-138.

Autore, D. M., Hutton, I., Peterson, D. R., \& Smith, A. H. (2014). The effect of securities litigation on external financing. Journal of Corporate Finance, 27, 231-250.

Basdas, U., \& Oran, A. (2014). Event studies in Turkey. Borsa Istanbul Review, 14(3), 167188.

Baucus, M. S., \& Baucus, D. A. (1997). Paying the piper: An empirical examination of longerterm financial consequences of illegal corporate behavior. Academy of Management Journal, 40(1), 129-151.

Becker, G. S. (1968). Crime and punishment: An economic approach. The economic dimensions of crime (pp. 13-68) Springer.

Campbell, J. L., Twedt, B. J., \& Whipple, B. C. (2016). Did regulation fair disclosure prevent selective disclosure? direct evidence from intraday volume and returns. Available at SSRN: Https://ssrn.com/abstract=2803308.

Chen, D., Jiang, D., Liang, S., \& Wang, F. (2011). Selective enforcement of regulation. China Journal of Accounting Research, 4(1), 9-27. 
Chen, G., Firth, M., Gao, D. N., \& Rui, O. M. (2005). Is China's securities regulatory agency a toothless tiger? evidence from enforcement actions. Journal of Accounting and Public Policy, 24(6), 451-488.

Chen, J. J., Cheng, X., Gong, S. X., \& Tan, Y. (2014). Do higher value firms voluntarily disclose more information? evidence from China. The British Accounting Review, 46(1), 1832 .

Chen, J., Cumming, D., Hou, W., \& Lee, E. (2016). Does the external monitoring effect of financial analysts deter corporate fraud in China? Journal of Business Ethics, 134(4), 727-742.

Cherry, T. L. (2001). Financial penalties as an alternative criminal sanction: Evidence from panel data. Atlantic Economic Journal, 29(4), 450-458.

Cheung, Y., Jiang, P., Limpaphayom, P., \& Lu, T. (2010). Corporate governance in China: A step forward. European Financial Management, 16(1), 94-123.

China Securities Regulatory Commission (CSRC). (2008). CSRC decree No.33: Provisions on banning the entry into the securities market. Retrieved from http://www.csrc.gov.cn/pub/csrc_en/laws/overRule/Decrees/201001/t20100126_175941.html

China Securities Regulatory Commission (CSRC). (2012). The notification on the supervision on the 2011 annual reports of listed companies. Retrieved from http://www.csrc.gov.cn/pub/csrc_en/newsfacts/release/201301/t20130105_220086.html

China Securities Regulatory Commission (CSRC). (2013). CSRC investor protection bureau responds to questions from investors. Retrieved from http://www.csrc.gov.cn/pub/csrc en/newsfacts/release/201303/t20130326_222638.html

China Securities Regulatory Commission (CSRC). (2014). Supervision transformation as the focus address--by CSRC chairman Xiao Gang on 2014 national conference on securities and futures supervision. Retrieved from http://www.csrc.gov.cn/pub/csrc_en/Informations/phgall/201402/t20140211_243696.html

China Securities Regulatory Commission (CSRC). (2016). CSRC 2015 annual report. Retrieved from http://www.csrc.gov.cn/pub/newsite/zjhjs/zjhnb/

D'Antoni, M., \& Galbiati, R. (2005). Deterrence and information: The optimal use of monetary and nonmonetary sanctions revisited. Available at SSRN: $\mathrm{Https}: / / \mathrm{ssrn}$.com/abstract=701424.

Desai, H., Hogan, C. E., \& Wilkins, M. S. (2006). The reputational penalty for aggressive accounting: Earnings restatements and management turnover. The Accounting Review, 81(1), 83-112.

Ding, Y., Zhang, H., \& Zhang, J. (2007). Private vs state ownership and earnings management: Evidence from Chinese listed companies. Corporate Governance: An International Review, 15(2), 223-238.

Du, L. (2017). The CDS market reaction to restatement announcements. Journal of Business Finance \& Accounting, 44(7-8), 1015-1035.

Elyasiani, E., \& Zhang, L. (2015). Bank holding company performance, risk, and "busy" board of directors. Journal of Banking \& Finance, 60, 239-251. 
Ewelt-Knauer, C., Knauer, T., \& Lachmann, M. (2015). Fraud characteristics and their effects on shareholder wealth. Journal of Business Economics, 85(9), 1011-1047.

Financial Conduct Authority (FCA). (2015). Annual report 2014/15. Retrieved from https://www.fca.org.uk/news/annual-report-14-15

Firth, M., Rui, O. M., \& Wu, X. (2009). The timeliness and consequences of disseminating public information by regulators. Journal of Accounting and Public Policy, 28(2), 118-132.

Firth, M., Wong, S., Xin, Q., \& Yick, H. Y. (2016). Regulatory sanctions on independent directors and their consequences to the director labor market: Evidence from China. Journal of Business Ethics, 134(4), 693-708.

Gneezy, U., \& Rustichini, A. (2000). A fine is a price. The Journal of Legal Studies, 29(1), 117.

Goodhart, C. (2017). Has regulatory reform been misdirected? Journal of Financial Regulation and Compliance, 25(3), 1-4.

Graham, J. R., Li, S., \& Qiu, J. (2008). Corporate misreporting and bank loan contracting. Journal of Financial Economics, 89(1), 44-61.

Hao, Q. (2016). Is there information leakage prior to share repurchase announcements? evidence from daily options trading. Journal of Financial Markets, 27(C), 79-101.

Hirshleifer, D., \& Teoh, S. H. (2003). Limited attention, information disclosure, and financial reporting. Journal of Accounting and Economics, 36(1), 337-386.

Hirst, D. E., Hopkins, P. E., \& Wahlen, J. M. (2004). Fair values, income measurement, and bank analysts' risk and valuation judgments. The Accounting Review, 79(2), 453-472.

Hitz, J., Ernstberger, J., \& Stich, M. (2012). Enforcement of accounting standards in Europe: Capital-market-based evidence for the two-tier mechanism in Germany. European Accounting Review, 21(2), 253-281.

Holmas, T. H., Kjerstad, E., Luras, H., \& Straume, O. R. (2010). Does monetary punishment crowd out pro-social motivation? A natural experiment on hospital length of stay. Journal of Economic Behavior \& Organization, 75(2), 261-267.

Huang, H. (2007). An empirical study of the incidence of insider trading in China. University of New South Wales Working Paper.

Huang, R. H. (2013). Private enforcement of securities law in China: A ten-year retrospective and empirical assessment. American Journal of Comparative Law, 61(4), 757-798.

Hung, M., Wong, T., \& Zhang, F. (2015). The value of political ties versus market credibility: Evidence from corporate scandals in China. Contemporary Accounting Research, 32(4), 16411675.

Israeli, D. (2015). Recognition versus disclosure: Evidence from fair value of investment property. Review of Accounting Studies, 20(4), 1457-1503. 
Jaafar, A., \& El-Shawa, M. (2009). Ownership concentration, board characteristics and performance: Evidence from Jordan. Accounting in emerging economies (pp. 73-95) Emerald Group Publishing Limited.

Jia, C., Ding, S., Li, Y., \& Wu, Z. (2009). Fraud, enforcement action, and the role of corporate governance: Evidence from China. Journal of Business Ethics, 90(4), 561-576.

Jiang, F., \& Kim, K. A. (2015). Corporate governance in China: A modern perspective. Journal of Corporate Finance, 32, 190-216.

Johnson, W. C., Xie, W., \& Yi, S. (2014). Corporate fraud and the value of reputations in the product market. Journal of Corporate Finance, 25, 16-39.

Karpoff, J., \& Lott, J. R. (1993). The reputational penalty firms bear from committing criminal fraud. Journal of Law and Economics, 36, 757-802.

Karpoff, J. M., Lee, D. S., \& Martin, G. S. (2007). The legal penalties for financial misrepresentation. Available at SSRN: Https://ssrn.com/abstract=933333.

Karpoff, J. M., Lee, D. S., \& Martin, G. S. (2008). The cost to firms of cooking the books. Journal of Financial and Quantitative Analysis, 43(3), 581-611.

Killias, M., Villettaz, P., \& Nunweiler-Hardegger, S. (2016). Higher fines-fewer traffic offences? A multi-site observational study. European Journal on Criminal Policy and Research, 22(4), 619-634.

Kim, H. (2013). Statistical notes for clinical researchers: Assessing normal distribution (2) using skewness and kurtosis. Restorative Dentistry \& Endodontics, 38(1), 52-54.

Kim, J., \& Zhang, L. (2016). Accounting conservatism and stock price crash risk: Firm-level evidence. Contemporary Accounting Research, 33(1), 412-441.

Kouwenberg, R., \& Phunnarungsi, V. (2013). Corporate governance, violations and market reactions. Pacific-Basin Finance Journal, 21(1), 881-898.

Kravet, T., \& Shevlin, T. (2010). Accounting restatements and information risk. Review of Accounting Studies, 15(2), 264-294.

Kurz, T., Thomas, W. E., \& Fonseca, M. A. (2014). A fine is a more effective financial deterrent when framed retributively and extracted publicly. Journal of Experimental Social Psychology, $54,170-177$.

Li, Y., Lou, F., Wang, J., \& Yuan, H. (2013). A survey of executive compensation contracts in China's listed companies. China Journal of Accounting Research, 6(3), 211-231.

Li, Y., Park, Y. I., \& Wynn, J. (2018). Investor reactions to restatements conditional on disclosure of internal control weaknesses. Journal of Applied Accounting Research, 19(3), 423439.

Lin, T., \& Lu, X. (2015). Why do options prices predict stock returns? Evidence from analyst tipping. Journal of Banking \& Finance, 52, 17-28.

Ma, L., Ma, S., \& Tian, G. (2016). Family control, accounting misstatements, and market reactions to restatements: Evidence from China. Emerging Markets Review, 28, 1-27. 
MacKinlay, A. C. (1997). Event studies in economics and finance. Journal of Economic Literature, 35(1), 13-39.

Michels, J. (2017). Disclosure versus recognition: Inferences from subsequent events. Journal of Accounting Research, 55(1), 3-34.

Modi, S. B., Wiles, M. A., \& Mishra, S. (2015). Shareholder value implications of service failures in triads: The case of customer information security breaches. Journal of Operations Management, 35, 21-39.

Moore, C., Stuart, H. C., \& Pozner, J. (2010). Avoiding the consequences of repeated misconducts: Stigma's licence and Stigma's transferability. Institute for Research on Labor and Employment Working Paper.

National People's Congress. (2009). Law of the people's republic of China on administrative penalty. Retrieved from http://www.lawinfochina.com/Display.aspx?lib=law\&ID=1148

Nosenzo, D., Offerman, T., Sefton, M., \& van der Veen, A. (2013). Encouraging compliance: Bonuses versus fines in inspection games. Journal of Law, Economics, and Organization, 30(3), 623-648.

Palmrose, Z., Richardson, V. J., \& Scholz, S. (2004). Determinants of market reactions to restatement announcements. Journal of Accounting and Economics, 37(1), 59-89.

Palmrose, Z., \& Scholz, S. (2004). The circumstances and legal consequences of non-GAAP reporting: Evidence from restatements. Contemporary Accounting Research, 21(1), 139-180.

Parker, C. (2006). The "compliance" trap: The moral message in responsive regulatory enforcement. Law \& Society Review, 40(3), 591-622.

Quan, Y., \& Li, S. (2017). Are academic independent directors punished more severely when they engage in violations? China Journal of Accounting Research, 10(1), 71-86.

Reuters. (2015). China stock market freezing up as sell-off gathers pace. Retrieved from http://www.reuters.com/article/us-china-stocks-idUSKCNOPI04Q20150708

Robbani, M. G., \& Bhuyan, R. (2010). Re-stating financial statements and its reaction in financial market: Evidence from Canadian stock market. International Journal of Accounting \& Information Management, 18(3), 188-197.

Song, C., \& Han, S. H. (2017). Stock market reaction to corporate crime: Evidence from South Korea. Journal of Business Ethics, 143(2), 323-351.

Staiger, D. O., \& Stock, J. H. (1997). Instrumental variables regression with weak instruments. 65, 557-586.

Steinway, S. (2014). SEC "monetary penalties speak very loudly," but what do they say? a critical analysis of the SEC's new enforcement approach. Yale Law Journal, 124, 209-232.

$\mathrm{Su}, \mathrm{C}$. (2015). Does institutional reform improve the impact of investment bank reputation on the long-term stock performance of initial public offerings? The British Accounting Review, 47(4), 445-470. 
Sun, P., \& Zhang, Y. (2006). (2006). Is there penalty for crime: Corporate scandal and management turnover in China. EFA 2006 Zurich Meetings Paper.

Swanepoel, A. P., \& Meiring, J. (2018). Adequacy of law enforcement and prosecution of economic crimes in South Africa. Journal of Financial Crime, 25(2), 450-466.

Tibbs, S. L., Harrell, D. L., \& Shrieves, R. E. (2011). Do shareholders benefit from corporate misconduct? A long-run analysis. Journal of Empirical Legal Studies, 8(3), 449-476.

Van-Erp, J. (2014). Naming and shaming of corporate offenders. Encyclopedia of criminology and criminal justice (pp. 3209-3217) Springer.

Weng, X., \& Jia, J. (2015). Assessing the administrative sanctions regime for insider trading in China: An empirical approach. Asian Journal of Comparative Law, 10(2), 343-358.

Werden, G. J. (2009). Sanctioning cartel activity: Let the punishment fit the crime. European Competition Journal, 5(1), 19-36.

World Bank. (2018). Data. Retrieved from https://data.worldbank.org/indicator/CM.MKT.LCAP.CD

Wu, W., Wu, C., \& Rui, O. M. (2012). Ownership and the value of political connections: Evidence from China. European Financial Management, 18(4), 695-729.

Wu, X., \& Zhang, J. (2014). Stock market reaction to regulatory investigation announcements. China Journal of Accounting Studies, 2(1), 37-52.

Xu, W., Chen, J., \& Xu, G. (2017). An empirical analysis of the public enforcement of securities law in China: Finding the missing piece to the puzzle. European Business Organization Law Review, 18(2), 367-389.

Xu, W., \& Xu, G. (2017). Understanding public enforcement of securities law in China: An empirical analysis of the enforcement outcomes of CSRC's regional offices. Available at SSRN: Https://ssrn.com/abstract=2912606.

Yang, D., Jiao, H., \& Buckland, R. (2017). The determinants of financial fraud in Chinese firms: Does corporate governance as an institutional innovation matter? Technological Forecasting and Social Change, 125, 309-320.

Yu, M. (2013). State ownership and firm performance: Empirical evidence from Chinese listed companies. China Journal of Accounting Research, 6(2), 75-87.

Zeidan, M. J. (2013). Effects of illegal behavior on the financial performance of US banking institutions. Journal of Business Ethics, 112(2), 313-324.

Zhang, J. (2018). Public governance and corporate fraud: Evidence from the recent anticorruption campaign in China. Journal of Business Ethics, 148(2), 375-396.

Zhang, L., \& Zhao, L. (2007). The punishment of corporate crime in China. International handbook of white-collar and corporate crime (pp. 663-679) Springer.

Zhu, J., \& Gao, S. S. (2011). Fraudulent financial reporting: Corporate behavior of Chinese listed companies. Accounting in Asia, 11, 61-82. 
Ziliak, S. T., \& McCloskey, D. N. (2013). We agree that statistical significance proves essentially nothing: A rejoinder to Thomas Mayer. Econ Journal Watch, 10(1), 97-107. 